\title{
Multi-inzetbaar in het Belgische privaatrecht: de vordering uit ongerechtvaardigde verrijking
}

Joke Baeck*

\section{Inleiding}

I. In België is de vordering uit ongerechtvaardigde verrijking een eerder marginale rechtsfiguur. ${ }^{628} \mathrm{Zij}$ krijgt weinig aandacht van de rechtsleer; ook in de rechtspraak komt zij weinig aan bod.

Dit staat schril in contrast met de belangstelling die deze rechtsfiguur in vele andere rechtsstelsels geniet. Zo is de law of restitution in Engeland al meer dan twintig jaar een van de meest bloeiende takken van het privaatrecht. ${ }^{629}$ Ook in Duitsland is de rechtsleer en rechtspraak over Ungerechtfertigte Bereicherung nauwelijks bij te houden. In Nederland voerde het nieuwe Burgerlijk Wetboek van 1992 een algemene vordering uit ongerechtvaardigde verrijking in. Zoals besproken in het Nederlandse preadvies van Ton Hartlief, gaf dit aanleiding tot heel wat rechtspraak en rechtsleer, die rond de milleniumwende hun hoogtepunt bereikten.

Ook in het Europees privaatrecht stijgt de interesse voor het leerstuk van de ongerechtvaardigde verrijking. Zo wijdt het Draft Common Frame of Reference (DCFR) een volledig boek aan Unjustified Enrichment. Daarnaast neemt ook de rechtspraak van het Hof van Justitie over ongerechtvaardigde verrijking toe. ${ }^{60}$ Zo erkende het Hof in 2008 dat de vordering uit ongerechtvaardigde verrijking deel uitmaakt van het Unierecht. ${ }^{6 \mathrm{I}}$ Verder toont het Hof zich ook niet weigerachtig tegenover een beroep op ongerechtvaardigde verrijking als verweermiddel, met name om een vordering te doen afwijzen indien de toewijzing ervan tot een ongerechtvaardigde verrijking van de eiser zou leiden. ${ }^{632}$

* Doctor-Assistent Universiteit Gent.

628 Vgl. W. van Gerven, Verbintenissenrecht, Leuven, Acco, 2006, $29 \mathrm{I}$.

629 A. Burrows, The law of restitution, Oxford, Oxford University Press, 20II, 7-8.

630 Zie A. S. Hartkamp, 'De horizontale werking van het (primaire) recht van de Europese Unie en het Nederlandse vermogensrecht', in: Vereniging voor de Vergelijkende Studie van het Recht van België en Nederland. Preadviezen 2011, Den Haag, Boom Juridische uitgevers, 20II, 332-333.

63I HvJ i6 december 2008, nr. C-47/07 P, Masdar.

632 Infra, nr. 62. 
2. De vraag rijst dan ook of de 'Belgische' vordering uit ongerechtvaardigde verrijking niet beter verdient. Om deze vraag te beantwoorden, is inzicht vereist in de functie die de vordering uit ongerechtvaardigde verrijking in het Belgische recht toekomt.

In dit preadvies zal worden toegelicht dat de vordering uit ongerechtvaardigde verrijking er in België uitsluitend op gericht is leemten in de wet op te vullen (paragraaf 2).

Om te weten in welke gevallen een vordering uit ongerechtvaardigde verrijking nuttig kan worden ingezet om een leemte in de wet op te vullen, is het van belang een goed zicht te hebben op de toepassingsvoorwaarden en de gevolgen van deze vordering. Hier wringt echter het schoentje. Aangezien de rechtsleer tot nu toe nog maar weinig oog heeft gehad voor de vordering uit ongerechtvaardigde verrijking, zijn zowel de toepassingsvoorwaarden als de gevolgen ervan weinig ontwikkeld. Gelet op de rechtsonzekerheid die dit meebrengt, is het dan ook begrijpelijk dat deze rechtsfiguur in de praktijk weinig succes kent.

Dit preadvies strekt ertoe deze vicieuze cirkel te doorbreken door, na beschrijving van de huidige stand van het recht, een eerste aanzet te geven tot verfijning van de toepassingsvoorwaarden (paragraaf 3 ) en de gevolgen (paragraaf 4 ) van de vordering uit ongerechtvaardigde verrijking. Langzaam maar zeker zal blijken dat deze vordering op verschillende domeinen van het privaatrecht nuttig kan worden ingezet. Verder zal ook worden onderzocht of, geïnspireerd door de rechtspraak van het Europese Hof van Justitie, in het Belgisch recht plaats is voor een beroep op ongerechtvaardigde verrijking als verweermiddel (paragraaf 5 ).

\section{Grondslag}

3. Anders dan naar Nederlands recht, heeft de vordering uit ongerechtvaardigde verrijking naar Belgisch recht geen uitdrukkelijke wettelijke grondslag. $\mathrm{Zij}$ is een creatie van de rechtspraak.

Het Hof van Cassatie heeft de vordering uit ongerechtvaardigde verrijking voor het eerst erkend in het Boswachtersarrest van 27 mei I909. ${ }^{633}$ Hiermee trad het Hof in de voetsporen van de Franse Cour de Cassation, die de vordering uit ongerechtvaardigde verrijking had aanvaard in het Boudier-arrest van 15 juni I892. ${ }^{634}$

633 Cass. 27 mei I909, Pas. I909, I, 272, concl. Terlinden. Dit arrest is tegelijk ook het eerste princiepsarrest inzake de tegenstelbaarheid van overeenkomsten aan derden (I. Claeys, Samenhangende overeenkomsten en aansprakelijkheid, Antwerpen, Intersentia, 2003, nr. IOI; E. Dirix, Obligatoire verhoudingen tussen contractanten en derden, Antwerpen, Kluwer, I984, I7-I8). Zie hierover ook infra, nr. 30.

634 Cass. fr. I5 juni I892, Recueil périodique de Dalloz I892, I, 596. 
De feiten die aanleiding gaven tot het Boswachtersarrest waren de volgende. Een boswachter had bij een ongeval levensbedreigende verwondingen opgelopen. Dankzij de goede zorgen van een geneesheer was de boswachter niet aan zijn verwondingen overleden en was hij slechts gedurende een korte periode arbeidsongeschikt geweest. Dit had ook gevolgen voor de ongevallenverzekeraar van de boswachter: deze was immers ontsnapt aan de betaling van een vergoeding wegens overlijden van de boswachter, of toch minstens aan de betaling van een arbeidsongeschiktheidsvergoeding gedurende een langere periode dan de werkelijke periode van arbeidsongeschiktheid van de boswachter. Volgens het bestreden vonnis hadden de door de geneesheer geleverde prestaties dan ook geleid tot een verrijking van de ongevallenverzekeraar, zodat deze veroordeeld werd om het ereloon voor deze prestaties te betalen.

Het Hof van Cassatie verbrak deze uitspraak, maar niet zonder eerst het bestaan van de vordering uit ongerechtvaardigde verrijking te erkennen. Het Hof overwoog namelijk: 'Attendu, en effet, que si le code, par les applications purement énonciatives et nullement limitatives qu'il fait de la maxime "Nul ne peut s'enrichir sans cause aux dépens d'autrui", marque bien qu'il a reconnu et sanctionné d'une manière générale ce principe d'équité, [...].' Volgens het Hof lag een vordering uit ongerechtvaardigde verrijking in het voorliggende geval echter niet voor, omdat de verrijking van de ongevallenverzekeraar niet 'zonder oorzaak' was. Op basis van het verzekeringscontract was de boswachter immers verplicht om zich bij een ongeval te laten verzorgen (op straffe van verlies van de vergoeding) en om de kosten hiervan zelf ten laste te nemen. Bijgevolg vormden de bepalingen van het verzekeringscontract de 'oorzaak' voor de verrijking van de ongevallenverzekeraar: zij stonden er aan in de weg dat de verzekeraar voor de kosten van de medische verzorging van de boswachter zou moeten opdraaien.

4. In het Boswachtersarrest gaf het Hof van Cassatie aan dat de grondslag voor de vordering uit ongerechtvaardigde verrijking gezocht moest worden in het 'billijkheidsprincipe' dat niemand zich ten koste van een ander ongerechtvaardigd mag verrijken.

Al gauw heerste eensgezindheid in de rechtspraak en de rechtsleer dat een beroep op dit billijkheidsprincipe - en dus op de vordering uit ongerechtvaardigde verrijking - in geen geval afbreuk mocht doen aan de wet en bijgevolg enkel kon worden toegelaten om leemten in de wet op te vullen. De vordering uit ongerechtvaardigde verrijking kreeg dan ook een subsidiair karakter: zij was enkel voorhanden indien de wet geen andere vorderingsmogelijkheid aan de eiser toekende. ${ }^{635}$

635 Vgl. J. Dabin, 'L'enrichissement sans cause' (noot onder Cass. 9 maart I950), RCJB I952, (8) 8 (over het billijkheidsprincipe dat niemand zich ten koste van een ander ongerechtvaardigd mag verrijken): 'Il ne faudra pas pourtant que le principe, en raison même de son caractère élémentaire, fît tort aux règles certaines de la loi positive au cas où celle-ci viendrait à consacrer ou à tolérer quelque enrichissement injuste en fait. Car le principe peut bien être appelé à compléter la loi là où elle est muette, mais non sans doute à la corriger ou à la contourner, voire même à la concurrencer par l'établissement d'une option entre elle et la voie légale.' Zie ook Brussel 9 juni I934, Pas. I935, II, 6; Rb. Brussel io juli I95I, JT I952, 23; 
5. Sinds 1983 heeft het Hof van Cassatie het billijkheidsprincipe dat niemand zich ten koste van een ander ongerechtvaardigd mag verrijken (ook wel het verrijkingsverbod genoemd), tot een algemeen rechtsbeginsel gepromoveerd..$^{6}{ }^{6}$ Voortaan kan de vordering uit ongerechtvaardigde verrijking dan ook als een toepassing van dit algemeen rechtsbeginsel worden gezien.

In de wet zijn echter ook nog andere, specifieke toepassingen van dit algemeen rechtsbeginsel terug te vinden. Te denken valt aan artikel 555 BW (op grond waarvan de eigenaar van een grond, die door natrekking eigenaar wordt van bouwwerken die een derde-bezitter ${ }^{637}$ op die grond heeft tot stand gebracht, onder bepaalde voorwaarden die derde-bezitter moet vergoeden), artikel $1376 \mathrm{BW}$ (dat een teruggaveplicht voor onverschuldigd ontvangen betalingen instelt) of aan artikel 1934 BW (op grond waarvan een bewaarnemer die de in bewaring gegeven zaak door overmacht is verloren en daarvoor een prijs of iets anders in de plaats heeft gekregen, het aldus ontvangene aan de bewaargever moet teruggeven). ${ }^{63}$

6. Dat de vordering uit ongerechtvaardigde verrijking voortaan niet meer louter op een billijkheidsprincipe, maar op een algemeen rechtsbeginsel kan worden gebaseerd, geeft deze vordering een meer solide basis. Dit verandert echter niets aan het subsidiair karakter van deze vordering. Voor zover zij niet in een wettelijke bepaling zijn neergelegd, zijn algemene rechtsbeginselen immers slechts bedoeld om leemten in de wet op te vullen. ${ }^{639}$ Aldus kan ook het algemeen rechtsbeginsel dat niemand zich ten koste van een ander ongerechtvaardigd mag verrijken, buiten de gevallen waarin de wet hiervan toepassing maakt, slechts worden ingeroepen indien de wet

Kh. Luik 20 april I946, JT I946, 354; Vred. Berchem 9 november I937, RW I937-38, I526; H. De Page, Traité élémentaire de droit civil belge, III, Brussel, Bruylant, I967, nr. 26B en 33B; R. Dekkers, Handboek burgerlijk recht, II, Brussel, Bruylant, I97I, nr. 3I6; K. Dewulf, noot onder Gent 29 januari I955, RW I954-55, (I632) I633-I634; A. Kluyskens, Beginselen van burgerlijk recht, I, De verbintenissen, Antwerpen, Standaard, I948, nr. 36o. Vgl. P. Van Ommeslaghe, Droit des obligations, II, Sources des obligations (deuxième partie), Brussel, Bruylant, 2010, nr. 776.

636 Cass. I7 november I983, Arr. Cass. I983-84, 315; Cass. I8 april I99I, Arr. Cass. I990-9I, 839; Cass. 7 september 200I, Arr. Cass. 200I, I395; Cass. I9 januari 2009, RW 2009-I0, 1084, noot E. Nordin; R. Kruithof, H. Bocken, F. De Ly en B. De Temmerman, 'Verbintenissen. Overzicht van rechtspraak (I98I-I992)', TPR I994, (I7I) 6I9, nr. 320; W. van Gerven, Verbintenissenrecht, Leuven, Acco, $2006,287$.

637 Infra, voetnoot 706.

638 Voor meer voorbeelden: zie R. Dekkers, Handboek burgerlijk recht, II, Brussel, Bruylant, I97I, nr. 3I3.

639 Vgl. A. Bossuyt, 'Algemene rechtsbeginselen in de rechtspraak van het Hof van Cassatie', TPR 2004, (I589) I646-I647, nr. 64; J. Vande Lanotte en G. Goedertier, Handboek Belgisch Publiekrecht, Brugge, die Keure, 20I0, nr. 268. Zie ook (over het subsidiair karakter van algemene rechtsbeginselen als rechtsbron): E. Krings, 'Aspects de la contribution de la Cour de cassation à l'édification du droit', JT I990, (545) 547, nr. II; Ganshof Van Der Meersch, 'Propos sur le texte de la loi et les principes généraux du droit', JT I970, (557) 567; J. Sace, 'Quelques réflexions sur les principes généraux du droit', in X (ed.), Mélanges Philippe Gérard, Brussel, Bruylant, 2002, 79; M. Van Hoecke, 'De algemene rechtsbeginselen als rechtsbron: een inleiding', in: M. Van Hoecke (ed.), Algemene rechtsbeginselen, Deurne, Kluwer, I99I, 5. 
een leemte vertoont. Een vordering uit ongerechtvaardigde verrijking staat dan ook niet open indien de wet reeds een andere actiemogelijkheid aan de eiser toekent. ${ }^{60}$

\section{Toepassingsvoorwaarden}

7. Traditioneel worden vijf voorwaarden aan de toepassing van de vordering uit ongerechtvaardigde verrijking gesteld: ${ }^{64}$

- een verrijking van de verweerder (paragraaf 3.I);

- een verarming van de eiser (paragraaf 3.2);

- een verband tussen de verarming en de verrijking (paragraaf 3.3);

- de afwezigheid van een juridische rechtvaardiging (paragraaf 3.4);

- de afwezigheid van andere vorderingsmogelijkheid (ook 'subsidiariteitsvereiste' genoemd) (paragraaf 3.5).

Hierna volgt een analyse van elk van deze toepassingsvoorwaarden. Daarnaast gaat ook aandacht naar de vraag of een fout van de eiser (zonder dewelke de ongerechtvaardigde verrijking niet had plaatsgevonden) een vordering uit ongerechtvaardigde verrijking uitsluit (paragraaf 3.6).

\section{I. Verrijking van de verweerder}

8. De vordering uit ongerechtvaardigde verrijking vereist vooreerst een verrijking van de verweerder. Vele auteurs beklemtonen dat het begrip 'verrijking' ruim moet worden opgevat, ${ }^{642}$ in die zin dat elk in geld waardeerbaar voordeel een verrijking oplevert. ${ }^{643}$

640 Vgl. evenwel W. van Gerven, Verbintenissenrecht, Leuven, Acco, 2006, 287: 'Men kan zich (...) afvragen waarom een rechtsbeginsel dat steunt op separate wetteksten, subsidiaire werking moet worden toegekend ten aanzien van die (of van andere) wetteksten - tenzij, in het enkele geval, dat men via het algemeen beginsel, een wetsbepaling van dwingende aard, zoals het verstrijken van een bevrijdende verjaring die de eiser door nalatigheid heeft laten verstrijken, probeert te omzeilen.'

64 I B. De Coninck, 'A titre subsidiaire, l'enrichissement sans cause...' in: P. Wéry (ed.), La théorie générale des obligations. Suite, Luik, Editions Formation Permanente CUP, 2002, 57-86; R. Dekkers, Handboek burgerlijk recht, II, Brussel, Bruylant, I97I, nrs. 3I4-3I6; R. Kruithof, H. Bocken, F. De Ly en B. De Temmerman, 'Verbintenissen. Overzicht van rechtspraak (I98I-I992)', TPR I994, (I7I) 6r9, nr. 320; C. Marr, 'L'enrichissement sans cause. Un fondement d'équité sous une apparente rigeur...', in: S. Stijns en P. Wéry (eds.), De bronnen van niet-contractuele verbintenissen, Brugge, die Keure, 2007, 214-240; V. Sagaert, 'Wat als het vermogen gaat schuiven? Casuïstiek rond zaakwaarneming, onverschuldigde betaling en ongerechtvaardigde verrijking', in: S. Stijns (ed.), Verbintenissenrecht, in: Themis, Brugge, die Keure, 2007, 88, nr. 26; W. van Gerven, Verbintenissenrecht, Leuven, Acco, 2006, 289-29I; P. Van Ommeslaghe, Droit des obligations, II, Sources des obligations (deuxième partie), Brussel, Bruylant, 2010, nr. 782.

642 W. van Gerven, Verbintenissenrecht, Leuven, Acco, 2006, 289.

643 B. De Coninck, 'A titre subsidiaire, l'enrichissement sans cause...' in: P. Wéry (ed.), La théorie générale des obligations. Suite, Luik, Editions Formation Permanente CUP, 2002, 58, nr. 4; H. De Page, Traité élémentaire de droit civil belge, III, Brussel, Bruylant, I967, nr. 37; C. Marr, 'L'enrichissement sans cause. Un fondement d'équité sous une apparente rigeur...', in: S. Stijns en P. Wéry (eds.), 
Bijgevolg kan de verrijking van de verweerder bestaan uit: de verkrijging van een goed, het genot over andermans goed, verbeteringen aan een goed van de verweerder, het (geheel of gedeeltelijk) tenietgaan van een schuld, een besparing van kosten, enz. ${ }^{64}$

9. Hoewel ook een dienstprestatie een in geld waardeerbaar voordeel is, geeft de ontvangst van een dienstprestatie door de verweerder in de huidige stand van het recht niet automatisch aanleiding tot een verrijking van de verweerder. Dit is slechts het geval indien (en in de mate waarin) de verweerder door de ontvangst van de dienstprestatie kosten heeft bespaard. Dit veronderstelt dat het gaat om kosten die de verweerder anders ook had gemaakt of had moeten maken. ${ }^{645}$

De invulling die het verrijkingsbegrip aldus in het kader van dienstprestaties krijgt, hangt samen met het - verder te bespreken - klassieke principe dat indien de voorwaarden voor een vordering uit ongerechtvaardigde verrijking vervuld zijn, de verweerder in principe aan de eiser een vergoeding moet betalen gelijk aan het bedrag van zijn verrijking (zonder dat deze vergoeding evenwel meer mag bedragen dan de verarming van de eiser). ${ }^{646}$

Indien de ontvangst van een dienstprestatie door de verweerder als dusdanig een verrijking zou uitmaken, zou de toepassing van dit principe meebrengen dat de verweerder een vergoeding zou moeten betalen, gelijk aan de geldelijke waarde, i.e. de gemiddelde marktprijs ${ }^{647}$ van de ontvangen dienstprestatie.

Stel bijvoorbeeld dat een advocaat een advies aflevert dat veel omstandiger is dan het advies waarom zijn cliënt had gevraagd. Indien de ongerechtvaardigde verrijking van de cliënt in dit geval zou bestaan uit het gedeelte van het advies waarom hij niet had gevraagd, dan zou de cliënt overeenkomstig het hierboven vermelde klassieke principe aan de advocaat een vergoeding moeten betalen, gelijk aan de gemiddelde marktprijs voor het gedeelte van het advies waarom hij niet had gevraagd. Dit zou erop neerkomen dat de cliënt gedwongen wordt te betalen voor het deel van het advies waarom hij niet heeft gevraagd. Dit zou regelrecht indruisen tegen het beginsel van de wilsautonomie, op grond waarvan elk individu de bevoegdheid heeft om

De bronnen van niet-contractuele verbintenissen, Brugge, die Keure, 2007, 215, nr. 8; V. Sagaert, 'Wat als het vermogen gaat schuiven? Casuïstiek rond zaakwaarneming, onverschuldigde betaling en ongerechtvaardigde verrijking', in: S. Stijns (ed.), Verbintenissenrecht, in: Themis, Brugge, die Keure, 2007, 88, nr. 27.

644 H. De Page, Traité élémentaire de droit civil belge, III, Brussel, Bruylant, I967, nr. 37; C. Marr, 'L'enrichissement sans cause. Un fondement d'équité sous une apparente rigeur...', in: S. Stijns en P. Wéry (eds.), De bronnen van niet-contractuele verbintenissen, Brugge, die Keure, 2007, 215, nr. 8.

645 H. De Page, Traité élémentaire de droit civil belge, III, Brussel, Bruylant, I967, nr. 37. Vgl. Rb. Brussel 24 mei r950, JT r95I, 90, noot J. Van Uytvanck.

646 Infra, nr. 47 .

647 Vgl. V. Sagaert, 'Unjustified Enrichment and Change of Position', MJ 2004, (I59) I76-I77, nr. 27. 
naar eigen goeddunken te beslissen of hij al dan niet wil contracteren en tegen welke voorwaarden hij zich wil verbinden. ${ }^{648}$

Indien echter, zoals in de huidige stand van het recht wordt aangenomen, de verrijking van de cliënt wordt vastgesteld op de kosten die hij door de ontvangst van het advies heeft bespaard, moet de cliënt maximaal deze kosten vergoeden. Indien de cliënt zelf geen kosten had gemaakt (of had moeten maken) voor het gedeelte van het advies waarom hij niet had gevraagd, zal hij bijgevolg voor dat gedeelte niets moeten betalen. Aldus wordt vermeden dat de cliënt moet betalen voor een prestatie die hij niet heeft gewild en wordt ook het beginsel van de wilsautonomie niet miskend.

Io. Het risico dat de verweerder op grond van de principes inzake ongerechtvaardigde verrijking verplicht zou worden te betalen voor een prestatie die hem werd opgedrongen, doet zich niet alleen voor wanneer de verweerder een dienstprestatie ontving, maar telkens wanneer hij een voordeel ontving dat niet vatbaar is voor teruggave in natura. Dit risico bestaat dus bijvoorbeeld ook wanneer de verweerder het genot van een goed heeft gehad of wanneer aan een goed van de verweerder verbeteringen werden aangebracht die niet vatbaar zijn voor teruggave in natura. Bijgevolg zou ook in deze gevallen de verrijking van de verweerder principieel beperkt moeten worden tot de kosten die hij door het verkregen voordeel heeft bespaard.

Stel dat een schilder de opdracht krijgt om de gevel van een woning te schilderen. Per vergissing schildert hij echter de gevel van de ernaast gelegen woning. Door de schilderwerken heeft de geschilderde woning een meerwaarde gekregen. Indien de eigenaar van de geschilderde woning deze meerwaarde steeds zou moeten vergoeden, ook wanneer hij zelf niet van plan was om zijn gevel te laten herschilderen, kan dit erop neerkomen dat hij moet betalen voor een prestatie die hij niet heeft gewild. Ook in deze casus verdient het bijgevolg de voorkeur dat de eigenaar van de geschilderde woning slechts gehouden zou zijn de kosten te vergoeden die hij door de schilderwerken heeft bespaard. Indien hij dus zelf niet van plan was om zijn gevel te laten herschilderen (of indien hij zijn gevel in een andere kleur wilde laten herschilderen), zal hij bijgevolg geen vergoeding verschuldigd zijn. ${ }^{649}$

II. Het verkrijgen van een voordeel dat niet vatbaar is voor teruggave in natura, maakt voor de verweerder echter niet steeds een opgedrongen prestatie uit.

Te denken valt aan een persoon die als verstekeling meereist in een vliegtuig van Brussel naar New York. In dat geval is geen sprake van een opgedrongen prestatie en

648 Vgl. (voor een omschrijving van het beginsel van de wilsautonomie): W. De Bondt, 'Precontractuele aansprakelijkheid', in: M. Storme (ed.), Recht halen uit aansprakelijkheid, in PUC Willy Delva 1992-93, Gent, Mys \& Breesch, I993, I49, nr. 4; J. H. Nieuwenhuis, Drie beginselen van contractenrecht, Deventer, Kluwer, I979, 6.

649 Vgl. Rb. Brussel 24 mei I950, JT I95I, 90, noot J. Van Uytvanck. 
valt moeilijk in te zien waarom de verrijking van de verstekeling beperkt zou moeten worden tot de kosten die hij door de vliegreis heeft bespaard (in casu: nihil omdat de verstekeling tegen betaling niet was meegevlogen). ${ }^{650}$

Het beginsel van de wilsautonomie ${ }^{651}$ rechtvaardigt inderdaad slechts een beperking van het verrijkingsbegrip indien de verrijking aan de verweerder werd opgedrongen. De verweerder moet de verrijking dus zonder zijn toestemming hebben verkregen.

I2. Technisch gezien is er nog een andere manier denkbaar om te vermijden dat de verweerder bij een vordering uit ongerechtvaardigde verrijking verplicht wordt om voor een opgedrongen prestatie te betalen. In plaats van het verrijkingsbegrip te beperken (zoals hierboven besproken), zou immers ook - zoals in het DCFR ${ }^{65}-\mathrm{de}$ restitutieplicht van de verweerder kunnen worden beperkt.

In dat geval zou, bij de beoordeling van de toepassingsvoorwaarden van de vordering uit ongerechtvaardigde verrijking, het bestaande uitgangspunt dat ieder in geld waardeerbaar voordeel een verrijking oplevert, onverkort kunnen gelden. ${ }^{63}$ Het is dan integendeel op het niveau van de gevolgen van de vordering uit ongerechtvaardigde verrijking, dat de restitutieplicht van de verweerder bij wege van uitzondering beperkt zou worden tot het bedrag van de door hem bespaarde kosten indien het voordeel niet vatbaar was voor teruggave in natura ${ }^{654}$ en de verweerder dit voordeel zonder zijn toestemming had verkregen. ${ }^{65}$

Verder in dit preadvies zal nog aan bod komen welke benadering (beperking van het verrijkingsbegrip dan wel beperking van de restitutieplicht van de verweerder) de voorkeur geniet. ${ }^{65} 6$

650 Dit voorbeeld is geïnspireerd op een in de Duitse en rechtsvergelijkende literatuur veelbesproken arrest van het Duitse Bundesgerichtshof van 7 januari I97I, Neue Juristische Wochenschrift 1971, 609 (over een verstekeling op een vlucht van Hamburg naar New York).

65 I Supra, nr. 9.

652 In het DCFR is elke prestatie die een economische waarde heeft, een verrijking (C. von Bar en E. Clive (eds.), Principles, Definitions and Model Rules of European Private Law. Draft Common Frame of Reference. Full edition, IV, München, Sellier, 2009, 4005 en 4007). Dit betekent echter nog niet dat de verrijkte steeds gehouden is de waarde van de verkregen verrijking te vergoeden. In het hoofdstuk over de omvang van de verbintenis uit ongerechtvaardigde verrijking bepaalt artikel VII. - 5/IO2 (I) en (2) DCFR immers het volgende voor niet-overdraagbare verrijkingen:

'VII. - 5:102: Non-transferable enrichment

(1) Where the enrichment does not consist of a transferable asset, the enriched person reverses the enrichment by paying its monetary value to the disadvantaged person.

(2) The enriched person is not liable to pay more than any saving if the enriched person:

(a) did not consent to the enrichment; or

(b) was in good faith.

(...)'

653 Supra, nr. 8.

654 Supra, nr. Io.

655 Supra, nr. II.

656 Infra, nr. 58. 


\subsection{Verarming van de eiser}

I3. Zoals gezien, vormt de vordering uit ongerechtvaardigde verrijking in de huidige stand een toepassing van het algemeen rechtsbeginsel dat niemand zich ten koste van een ander ongerechtvaardigd mag verrijken. ${ }^{65}$

Traditioneel wordt de vereiste dat geen ongerechtvaardigde verrijking 'ten koste van een ander' mag plaatsvinden, zo geïnterpreteerd dat er een verarming van die ander (de verweerder) moet hebben plaatsgevonden. ${ }^{658}$ Deze verarming kan bestaan uit: het verlies van een goed, het verlies van het genot over een goed, het verrichten van een dienstprestatie zonder daarvoor vergoed te worden, enz. ${ }^{659}$

I4. Naar Belgisch positief recht kan de vordering uit ongerechtvaardigde verrijking dus niet als een loutere vordering tot voordeelsafgifte worden opgevat. Een verarming van de eiser is immers steeds vereist.

Dit is niet in alle rechtsstelsels het geval. ${ }^{60}$

Zo kent het Engelse recht het leerstuk van de restitution for wrongs, op basis waarvan iemand die jegens een ander een wrong ${ }^{66 r}$ heeft begaan en hierdoor werd verrijkt, onder bepaalde voorwaarden gehouden is die verrijking aan die ander over te dragen, zonder dat een verarming van die ander vereist is. ${ }^{662}$

Verder laat het Duitse recht een vordering uit ongerechtvaardigde verrijking onder bepaalde voorwaarden toe indien de verweerder zich ongerechtvaardigd heeft verrijkt door een inbreuk op een recht van de eiser, ook al ging die inbreuk niet gepaard met een daadwerkelijke verarming van de eiser. Dit is de zogenaamde Eingriffskondiktion, een subcategorie van de vordering uit Ungerechtfertigte Bereicherung. ${ }^{66_{3}}$

In het DCFR is een gelijkaardige benadering terug te vinden: voor een vordering uit ongerechtvaardigde verrijking is geen verarming van de eiser vereist, maar volstaat

657 Supra, nr. 5 .

658 B. De Coninck, 'A titre subsidiaire, l'enrichissement sans cause...', in: P. Wéry (ed.), La théorie générale des obligations. Suite, Luik, Editions Formation Permanente CUP, 2002, 6o, nr. 7; H. De Page, Traité élémentaire de droit civil belge, III, Brussel, Bruylant, I967, nr. 38; C. Marr, 'L'enrichissement sans cause. Un fondement d'équité sous une apparente rigeur...', in: S. Stijns en P. Wéry (eds.), De bronnen van niet-contractuele verbintenissen, Brugge, die Keure, 2007, 2I6, nr. 8; V. Sagaert, 'Wat als het vermogen gaat schuiven? Casuïstiek rond zaakwaarneming, onverschuldigde betaling en ongerechtvaardigde verrijking', in: S. Stijns (ed.), Verbintenissenrecht, in Themis, Brugge, die Keure, 2007, 89, nr. 28; W. van Gerven, Verbintenissenrecht, Leuven, Acco, 2006, 289.

659 H. De Page, Traité élémentaire de droit civil belge, III, Brussel, Bruylant, I967, nr. 38.

66o Zie ook R. Zimmermann, 'Unjustified Enrichment: The Modern Civilian Approach', Oxford J. Legal Stud. I995, (403) 4I8-42I.

66I Deze wrong kan bestaan uit een contractuele fout (breach of contract), een onrechtmatige daad (tort) of een schending van een fiduciary duty.

662 Zie A. Burrows, The law of restitution, Oxford, Oxford University Press, 20II, 62 I-705.

663 Zie G. Dannemann, The German Law of Unjustified Enrichment and Restitution, Oxford, Oxford University Press, 2009, 9I-I03. 
het dat de ongerechtvaardigde verrijking 'ten nadele van' de eiser plaatsvond. ${ }^{664}$ Hiervan is onder meer sprake wanneer de verweerder zich ongerechtvaardigd heeft verrijkt door het gebruik van een vermogensbestanddeel ${ }^{665}$ van de eiser ${ }^{666}$, zonder dat daarbij vereist is dat de eiser door dit gebruik daadwerkelijk werd verarmd. Uit de toelichting bij het DCFR blijkt dat het gebruik van een vermogensbestanddeel van de eiser bijvoorbeeld kan bestaan uit het gebruik van een (intellectueel) eigendomsrecht van de eiser of uit het gebruik van een persoonlijkheidsrecht van de eiser (voor zover het gaat om een recht dat vatbaar is voor commerciële exploitatie). ${ }^{667}$

I5. Ook in België zou het in bepaalde gevallen nuttig zijn een vordering tot voordeelsafgifte toe te laten.

Te denken valt aan situaties waarin een inbreuk op een intellectueel eigendomsrecht of een persoonlijkheidsrecht werd gepleegd, waardoor de inbreukpleger een voordeel (een verrijking) heeft genoten dat groter is dan het nadeel (de schade) die de titularis van het recht door de inbreuk heeft geleden.

Stel bijvoorbeeld dat een filmmaker een boek wil laten verfilmen. Bij de onderhandelingen eist de auteur van het boek een vergoeding van $€ 30.000$ voor de verfilming ervan. Hierop springen de onderhandelingen af. Vervolgens maakt de filmmaker een speelfilm waarin de verhaallijn van het boek duidelijk te herkennen is. De film wordt een kaskraker en levert de filmmaker een nettowinst van $€ 300.000$ op.

Of stel dat een brouwerij een foto in handen krijgt van een bekend acteur die een blikje door haar gebrouwen bier drinkt. Vervolgens gebruikt de brouwerij deze foto zonder toestemming van de acteur voor een succesvolle reclamecampagne.

Indien het onrechtmatigedaadsrecht in deze gevallen wordt toegepast, zal de titularis van het miskende recht enkel aanspraak kunnen maken op vergoeding van zijn schade, die hoogstwaarschijnlijk lager zal uitvallen dan de winst die de inbreukpleger heeft weten te realiseren. Dit leidt tot het onbevredigende resultaat dat de inbreukpleger zelfs na schadeloosstelling van het slachtoffer een verrijking aan de inbreuk overhoudt, zodat hij niet geprikkeld wordt om de inbreuk niet te begaan.

Een treffend voorbeeld uit de Belgische rechtspraak betrof een zaak waarin Omega Pharma, een groot farmaceutisch bedrijf, de naam van de tennisster Kim Clijsters zonder toestemming had gebruikt voor een reclamecampagne voor haar

664 Cf. artikel VII. - I:IOI DCFR, waarin sprake is van 'an unjustified enrichment which is attributable to another's disadvantage'.

665 Voor de vertaling van 'assets' als ‘vermogensbestanddelen': zie C. von Bar en S. Swann, Unjustified Enrichment, in: Principles of European Law, Volume 8, München, Sellier, 2010, I6.

666 Cf. artikel VII. - 3:IO2 (I) (c) DCFR over het begrip 'disadvantage': '(1) A person is disadvantaged by (c) another's use of that person's assets.'

667 C. von Bar en E. Clive (eds.), Principles, Definitions and Model Rules of European Private Law. Draft Common Frame of Reference. Full edition, IV, München, Sellier, 2009, 4005. 
doucheproducten. Volgens de rechtbank van eerste aanleg te Gent had Omega Pharma aldus een onrechtmatige daad begaan, zodat zij aansprakelijk was voor de schade die Kim Clijsters hierdoor had geleden. Vervolgens oordeelde de rechtbank dat Kim Clijsters geen materiële schade had geleden, maar enkel morele schade, die op $€$ I werd begroot. ${ }^{668}$ Voor Omega Pharma was dit dus wel een heel goedkope reclamecampagne...669

I6. In de praktijk blijken sommige feitenrechters naar oplossingen te zoeken om ervoor te zorgen dat de toepassing van het onrechtmatige daadsrecht bij inbreuken op intellectuele eigendomsrechten of persoonlijkheidsrechten toch tot een enigszins aanvaardbaar resultaat leidt. Zo springen zij soms erg creatief om met schadeposten bij de toekenning van schadevergoeding wegens inbreuken op intellectuele eigendomsrechten. Bij inbreuken op persoonlijkheidsrechten wordt dan weer dikwijls (maar lang niet altijd) een royale vergoeding voor morele schade toegekend.

Hoewel goed bedoeld, botsen deze oplossingen op kritiek.

Zo waarschuwde het Hof van Cassatie er in een arrest van 13 mei 2009 nog voor dat ook het slachtoffer van een inbreuk op een intellectueel eigendomsrecht op grond van artikel $1_{3} 82 \mathrm{BW}$ slechts aanspraak kan maken op vergoeding van zijn schade. Op grond van deze wetsbepaling kan de rechter dus geen hogere vergoeding toekennen, ook niet met de bedoeling om inbreuken op intellectuele eigendomsrechten te ontraden. ${ }^{670}$

Ook de toekenning van hoge morele schadevergoedingen bij inbreuken op persoonlijkheidsrechten komt vaak nogal geforceerd over. Bovendien lopen de bedragen van de toegekende vergoedingen sterk uiteen, wat een erg arbitraire indruk geeft. ${ }^{67 \mathrm{r}}$

I7. Om ervoor te zorgen dat potentiële inbreukplegers meer geprikkeld worden om zich van een inbreuk op een persoonlijkheidsrecht of intellectueel eigendomsrecht te onthouden, pleit sommige rechtsleer zeer voorzichtig voor de invoering van punitive damages in het Belgische onrechtmatige daadsrecht. ${ }^{672}$ Deze laten immers

$668 \mathrm{Rb}$. Gent I9 november 2003, A \& M 2004, 384.

669 Vgl. B. Weyts, 'Lucratieve fouten in het aansprakelijkheids- en verzekeringsrecht. The winner takes it all', RW 2005-06, (I64I) I64I, nr. 2.

670 Cass. I3 mei 2009, AR P.o9.or2I.F. Zie ook H. Bocken en I. Boone, Inleiding tot het schadevergoedingsrecht, Brugge, die Keure, 20II, nr. 329; J. Deene, 'Intellectuele rechten. Kroniek 2009', NjW 2010, (474) 490, nr. I34.

67 I G. Baeteman, J. Gerlo, E. Guldix, A. Wylleman, G. Verschelden en S. Brouwers, 'Personen- en familierecht. Overzicht van rechtspraak (I995-2000)', TPR 200I, (I55I) I700, nr. 2 II.

672 E. Guldix en A. Wylleman, 'De positie en de handhaving van persoonlijkheidsrechten in het Belgisch privaatrecht', TPR I999, (I589) I654-I655, nr. 44; B. Weyts, 'Lucratieve fouten in het aansprakelijkheids- en verzekeringsrecht. The winner takes it all', RW 2005-06, (I64I) I650-I65I, nrs. $27-30$. 
toe een vergoeding toe te kennen die het bedrag van de werkelijk geleden schade te boven gaat, met het doel een bepaald gedrag te bestraffen of te ontraden. ${ }^{673}$

De rechtsfiguur van de punitive damages valt echter niet te verzoenen met een van de basisbeginselen uit het onrechtmatigedaadsrecht, nl. dat indien aan de voorwaarden van een vordering uit onrechtmatige daad is voldaan, de volledige schade moet worden vergoed. Niet minder, maar ook niet meer. ${ }^{674}$ Bovendien bestaat de vrees voor 'Amerikaanse toestanden', waarbij soms astronomische bedragen als punitive damages worden toegekend.

I8. De aanvaarding van een vordering tot voordeelsafgifte kan echter een goed alternatief bieden om aan het hierboven geschetste probleem tegemoet te komen.

Recent bepleitte een auteur de invoering van een dergelijke vordering in het Belgische recht. Volgens hem kan in het positieve privaatrecht een algemeen rechtsbeginsel worden ontwaard op basis waarvan de titularis van een subjectief recht de overdracht kan eisen van alle voordelen, opbrengsten of winsten die een ander heeft kunnen verwezenlijken door middel van de miskenning te kwader trouw van de zeggenschap die het geschonden subjectief recht exclusief aan hem toekent. Het is op dit algemeen rechtsbeginsel dat hij de vordering tot voordeeloverdacht steunt. ${ }^{675}$

I9. Een vordering tot voordeeloverdracht zou echter ook kunnen worden gekaderd in het leerstuk van de ongerechtvaardigde verrijking, mits een soepelere invulling wordt gegeven aan het vereiste dat de ongerechtvaardigde verrijking 'ten koste' van de eiser moet hebben plaatsgevonden, in die zin dat deze vereiste niet steeds een verarming van de eiser veronderstelt, maar dat in sommige gevallen een inbreuk op een recht van de eiser volstaat.

Om te bepalen in welke gevallen een vordering uit ongerechtvaardigde verrijking wegens inbreuk op een recht van de eiser mogelijk is, kan worden teruggegrepen naar ons uitgangspunt dat een vordering uit ongerechtvaardigde verrijking naar Belgisch recht enkel bedoeld is om leemten in de wet op te vullen. ${ }^{676}$ Aldus zou een vordering uit ongerechtvaardigde verrijking wegens inbreuk op een recht van de eiser enkel openstaan in die gevallen waarin de wet een leemte vertoont. Dit is bijvoorbeeld het geval wanneer de wet zelf onvoldoende prikkels bevat om potentiële inbreukplegers van een onrechtmatige inbreuk op andermans recht te weerhouden. Zoals hoger gezien, doet zich dit in de praktijk dikwijls voor bij onrechtmatige inbreuken op intellectuele eigendomsrechten of persoonlijkheidsrechten, wanneer de toepassing van het onrechtmatigedaadsrecht ertoe leidt dat de inbreukpleger,

$673 \mathrm{H}$. Bocken en I. Boone, Inleiding tot het schadevergoedingsrecht, Brugge, die Keure, 20II, nr. 329.

674 H. Bocken en I. Boone, Inleiding tot het schadevergoedingsrecht, Brugge, die Keure, 20II, nr. 328; P. Van Ommeslaghe, Droit des obligations, II, Sources des obligations (deuxième partie), Brussel, Bruylant, 20I0, nr. III8.

675 M. Kruithof, 'De vordering tot voordeeloverdracht', TPR 20II, I3-66.

676 Supra, nr. 6. 
zelfs na schadeloosstelling van de titularis, aan de inbreuk een verrijking overhoudt. ${ }^{677}$

\subsection{Verband tussen verrijking en verarming}

20. Dat de ongerechtvaardigde verrijking van de verweerder ten koste van de eiser moet zijn geschied, betekent dat tussen de verrijking van de verweerder en de verarming van de eiser (of de inbreuk op het recht van de eiser ${ }^{678}$ ) een verband moet bestaan.

Dit verband kan rechtstreeks zijn (directe verrijking), maar kan ook via een derde tot stand gekomen zijn (indirecte verrijking).

Een indirecte verrijking doet zich bijvoorbeeld voor wanneer een aannemer op verzoek van een huurder verbeteringswerken aan het gehuurde goed heeft uitgevoerd, maar door de huurder niet werd betaald. In dit geval is sprake van een verrijking van de eigenaar van het gehuurde goed (de verbeteringswerken komen hem immers op het einde van de huur bij wege van natrekking ten goede ${ }^{679}$ ) ten koste van de aannemer (die de verbeteringswerken heeft uitgevoerd zonder daarvoor vergoed te worden). De verrijking van de verhuurder ten koste van de aannemer vond niet rechtstreeks plaats, maar door tussenkomst van een derde, nl. de huurder die opdracht had gegeven voor de werken. Of de aannemer in dit geval daadwerkelijk over een vordering uit ongerechtvaardigde verrijking tegen de verhuurder beschikt, komt verderop nog aan bod. ${ }^{680}$

Van een indirecte verrijking is ook sprake bij afroep van een bankgarantie op eerste verzoek, wanneer naderhand blijkt dat de afroep niet terecht is gebeurd. Stel dat een huurder aan de verhuurder een bankgarantie heeft verstrekt tot waarborg van de eventuele huurschade bij de beëindiging van de huur. Na de beëindiging van de huurovereenkomst ontstaat tussen partijen betwisting over het bestaan en de omvang van de huurschade. Hierop gaat de verhuurder over tot afroep van de bankgarantie. De bank betaalt de verhuurder het overeengekomen bedrag; het feit dat de schuldvordering van de verhuurder betwist is, staat hier immers niet aan in de weg. Vervolgens debiteert de bank de rekening van de huurder met het bedrag dat zij aan de verhuurder heeft betaald. Naderhand komt echter vast te staan dat er geen huurschade is. In dat geval is sprake van een verrijking van de verhuurder (die van de bank een geldsom had ontvangen) ten koste van de huurder (wiens bankrekening met het door de bank betaalde bedrag gedebiteerd werd). Deze verrijking van de verhuurder ten koste van de huurder vond niet rechtstreeks plaats, maar door tussenkomst van een derde, nl. de bank. Aangezien voor de verrijking van de verhuurder ten koste

677 Over de omvang van de verbintenis van de inbreukpleger: infra, nr. 56 .

678 Supra, nr. I9.

679 Infra, nr. 29.

68 o Infra, nr. 43 . 
van de huurder geen juridische rechtvaardiging bestaat, zal de huurder - bij gebrek aan andere actiemogelijkheid - over een vordering uit ongerechtvaardigde verrijking tegen de verhuurder beschikken om de door de bank betaalde bedragen terug te vorderen. ${ }^{68 \mathrm{I}}$

\subsection{Gebrek aan juridische rechtvaardiging}

2I. Volgens de rechtspraak van het Hof van Cassatie staat een vordering uit ongerechtvaardigde verrijking slechts open indien de verrijking van de verweerder ten koste van de eiser 'zonder oorzaak' is. ${ }^{682}$ Naar Belgisch recht is het begrip 'oorzaak' echter niet eenduidig. ${ }^{683}$

Om verwarring te vermijden, wordt in deze bijdrage dan ook de voorkeur gegeven aan een andere terminologie die in de literatuur soms wordt gebruikt, nl. dat de verrijking van de verweerder ten koste van de eiser '(juridisch) ongerechtvaardigd' moet zijn. ${ }^{684}$ Hiermee wordt bedoeld dat de verrijking van de verweerder ten koste van de eiser 'in de ogen van het recht' geen rechtvaardiging mag hebben. ${ }^{68}$

In de huidige stand van het recht staat het niet ter discussie dat een verrijking van de verweerder ten koste van de eiser haar rechtvaardiging kan vinden in een wet (paragraaf 3.4.I), een contract (paragraaf 3.4.2) of de eigen wil van de verarmde (paragraaf 3.4.3). Verder is een verrijking van de verweerder ten koste van de eiser ook gerechtvaardigd indien de eiser met een speculatief oogmerk handelde (paragraaf 3.4.4) of indien hij uitsluitend de behartiging van zijn eigen belangen nastreefde (paragraaf $3 \cdot 4 \cdot 5$ ).

68I In een arrest van 28 juni 2012 (C.Ir.0723.N) geeft het Hof van Cassatie duidelijk aan dat 'de opdrachtgever van de garantie (gerechtigd) is de krachtens de garantie betaalde bedragen van de begunstigde terug te vorderen wanneer de afroep niet terecht is gebeurd.' Hoewel het Hof dit niet uitdrukkelijk vermeldt, moet worden aangenomen dat deze terugvordering moet gebeuren op grond van de principes inzake ongerechtvaardigde verrijking (vgl. voor Frankrijk: P. Ancel, Droit des sûretés, Parijs, LexisNexis, 20II, nr. I78).

682 Zie o.m. Cass. 27 mei I909, Pas. I909, I, 272, concl. Terlinden; Cass. 9 maart I950, Arr. Verbr. I950, 46I, RCJB I952, 5, noot J. Dabin; Cass. 7 april I978, RW I978-79, I359; Cass. I8 april I99I, RW I99394, I065; Cass. 7 september 200I, Arr. Cass. 200I, I395; Cass. 25 april 2006, RW 2009-I0, 4I7; Cass. Io mei 2012, AR C.10.0707.N.

683 Vgl. E. Dirix, Obligatoire verhoudingen tussen contractanten en derden, Antwerpen, Kluwer, I984, nr. 314: '(Wanneer) het begrip oorzaak ten berde komt, (beginnen) de betwistingen tussen de auteurs.' Zie ook B. De Coninck, 'A titre subsidiaire, l'enrichissement sans cause...', in: P. Wéry (ed.), La théorie générale des obligations. Suite, Luik, Editions Formation Permanente CUP, 2002, 6I, nr. 9: 'La notion de "cause" est souvent l'objet de controverses de doctrine interminables et l'acceptation qu'il convient de lui donner en matière d'enrichissement sans cause n'y échappe pas.'

684 Zie o.m. V. Sagaert, 'Wat als het vermogen gaat schuiven? Casuïstiek rond zaakwaarneming, onverschuldigde betaling en ongerechtvaardigde verrijking', in: S. Stijns (ed.), Verbintenissenrecht, in Themis, Brugge, die Keure, 2007, 89, nr. 29. Vgl. E. Dirix, 'Ongerechtvaardigde verrijking in drie-partijen-verhoudingen', TPR I98I, (I023) I025, nr. 2.

685 Vgl. H. De Page, Traité élémentaire de droit civil belge, III, Brussel, Bruylant, I967, nr. 32. 
Volgens sommige auteurs mag ook geen economische of morele rechtvaardiging voorhanden zijn voor de verrijking van de verweerder ten koste van de eiser. ${ }^{686}$ In de praktijk lijkt deze zienswijze echter nauwelijks weerklank te vinden. Wel heerst eensgezindheid dat geen vordering uit ongerechtvaardigde verrijking voorligt indien de eiser in uitvoering van een natuurlijke verbintenis handelde. In dat geval is voor de verrijking van de verweerder ten koste van de eiser echter evenzeer een juridische rechtvaardiging voorhanden (paragraaf 3.4.6).

22. Alvorens al deze verschillende hypothesen te bespreken, moet nog worden opgemerkt dat geen vordering uit ongerechtvaardigde verrijking openstaat zodra een juridische rechtvaardiging aanwezig is, hetzij voor de verrijking van de verweerder, hetzij voor de verarming van de eiser ${ }^{687}$ (of de inbreuk op het recht van de eiser).

Verder gaf het Hof van Cassatie in een arrest van Io mei 2012 terecht aan dat de verrijking van de verweerder ten koste van de eiser ongerechtvaardigd is indien noch voor de verrijking van de verweerder, noch voor de verarming van de eiser (of de inbreuk op het recht van de eiser) een rechtsgrond kan worden aangewezen. ${ }^{688}$

Het omgekeerde geldt echter niet: het is niet omdat voor de verrijking van de verweerder een rechtsgrond bestaat, dat die verrijking automatisch gerechtvaardigd is. ${ }^{68 / 690}$ Zo leidt eigendomsverkrijging door natrekking tot een verrijking van de eigenaar van de hoofdzaak. Deze verrijking is niet zonder rechtsgrond (want zij steunt op de wet), maar is - zoals verder nog zal blijken ${ }^{691}-$ meestal wel ongerechtvaardigd indien zij onvergoed zou blijven. ${ }^{692}$

\subsubsection{Rechtvaardiging door de wet}

23. Een vordering uit ongerechtvaardigde verrijking is uitgesloten indien de verrijking van de verweerder ten koste van de eiser haar rechtvaardiging vindt in de wet. ${ }^{693}$

686 B. De Coninck, 'A titre subsidiaire, l'enrichissement sans cause...', in: P. Wéry (ed.), La théorie générale des obligations. Suite, Luik, Editions Formation Permanente CUP, 2002, 6I, nr. 9 ; P. Van Ommeslaghe, Droit des obligations, II, Sources des obligations (deuxième partie), Brussel, Bruylant, 20Io, nr. 785 .

687 A. De Bersaques, 'Le caractère subsidiaire de l'actio de in rem verso' (noot onder Gent 29 januari I955), RCJB I957, (I20) I24, nr. 8.

688 Cass. Io mei 2012, AR C.10.0707.N.

689 Vgl. P. Van Ommeslaghe, Droit des obligations, II, Sources des obligations (deuxième partie), Brussel, Bruylant, 2010, nr. 785 .

690 Om die reden is de ook wel gebruikte term 'ongegronde' verrijking, eerder misleidend.

69 I Infra, nr. 26.

692 Vgl. (voor Nederland): J. Spier, T. Hartlief, G. E. Van Maanen en R. D. Vriesendorp, Verbintenissen uit de wet en schadevergoeding, in: Studiereeks burgerlijk recht, Deventer, Kluwer, 2009, nr. 3I4.

693 H. De Page, Traité élémentaire de droit civil belge, III, Brussel, Bruylant, I967, 40C; R. Kruithof, H. Bocken, F. De Ly en B. De Temmerman, 'Verbintenissen. Overzicht van rechtspraak (I98II992)', TPR 1994, (I7I) 623, nr. 325; W. van Gerven, Verbintenissenrecht, Leuven, Acco, 2006, 290; P. Van Ommeslaghe, Droit des obligations, II, Sources des obligations (deuxième partie), Brussel, Bruylant, 20I0, nr. 786 . 
24. Wanneer de toepassing van een wettelijke bepaling ertoe leidt dat de verweerder ten koste van de eiser wordt verrijkt, betekent dit nog niet dat de verrijking van de verweerder 'door de wet gerechtvaardigd' is. ${ }^{694}$ Dit is enkel het geval indien uit de strekking van die wettelijke bepaling blijkt dat het niet de bedoeling van de wetgever was dat de verweerder voor de verkregen verrijking aan de eiser een vergoeding zou moeten betalen. In de huidige stand van het recht wordt dit echter veel te weinig benadrukt.

25. Een mooi voorbeeld van een door de wet gerechtvaardigde verrijking betreft de situatie waarin een bezitter te goeder trouw op grond van artikel 549 BW de vruchten mag houden. Aldus wordt de bezitter te goeder trouw verrijkt ten koste van de eigenaar, aan wie de vruchten immers in principe op grond van artikel $547 \mathrm{BW}$ toebehoren. Zoals bekend, strekt de regel van artikel 549 BW ertoe het rechtmatig vertrouwen van de bezitter te goeder trouw te beschermen. Deze bescherming zou volledig worden uitgehold indien de bezitter voor het behoud van de vruchten een vergoeding zou moeten betalen. Aldus kan het niet de bedoeling van de wetgever geweest zijn dat de bezitter een dergelijke vergoeding aan de eigenaar zou moeten betalen. De eigenaar beschikt dan ook niet over een vordering uit ongerechtvaardigde verrijking voor de vruchten die de bezitter te goeder trouw mag houden. ${ }^{695}$

Een ander voorbeeld is artikel 98 Marktpraktijkenwet, op grond waarvan degene die in strijd met het verbod van afgedwongen aankoop goederen ontving, deze goederen mag behouden, zonder daarvoor een vergoeding te moeten betalen. Een vordering uit ongerechtvaardigde verrijking tegen de geadresseerde van de goederen zal bijgevolg geen kans op slagen hebben.

26. Er zijn evenwel ook wettelijke bepalingen die ertoe leiden dat iemand ten koste van een ander wordt verrijkt, maar waaruit niet kan worden afgeleid dat het de bedoeling van de wetgever was dat die verrijking onvergoed zou blijven.

Reeds hoger werd verwezen naar de regels van het BW inzake natrekking, op grond waarvan de eigenaar van de hoofdzaak ook eigenaar van de bijzaak wordt. Uit deze regels kan niet worden afgeleid dat de verrijking die de eigenaar van de hoofdzaak aldus verkrijgt, onvergoed zou moeten blijven. Bijgevolg is een vordering uit ongerechtvaardigde verrijking tegen de eigenaar mogelijk, voor zover de wet zelf geen (vergoedings)regeling vaststelt. ${ }^{696}$

27. Wanneer iemand op grond van een wettelijke bepaling ten koste van een ander wordt verrijkt, moet bijgevolg van geval tot geval worden nagegaan of het de bedoeling van de wetgever was dat die verrijking onvergoed zou blijven. Slechts wanneer

694 Vgl. supra, nr. 22.

695 Vgl. P. Van Ommeslaghe, Droit des obligations, II, Sources des obligations (deuxième partie), Brussel, Bruylant, 20Io, nr. 786.

696 Gelet op het subsidiair karakter van de vordering uit ongerechtvaardigde verrijking. 
dit niet het geval is, is een vordering uit ongerechtvaardigde verrijking mogelijk (tenminste voor zover ook aan de subsidiariteitsvoorwaarde ${ }^{697}$ is voldaan).

Interessant in dit verband is een arrest van het hof van beroep te Luik van 23 maart I989. ${ }^{698}$ In uitvoering van een door een verkavelingsvergunninig opgelegde verplichting hadden appellanten een riolering voor hun perceel laten aanleggen. Later profiteerden ook geïntimeerden van de aldus uitgevoerde werken, omdat de riolering voor hun perceel op de door appellanten aangelegde riolering werd aangesloten. Hierop stelden appellanten een vordering uit ongerechtvaardigde verrijking in tegen geïntimeerden. Geïntimeerden waren immers verrijkt (doordat zij kosten voor de aanleg van de riolering hadden uitgespaard) ten koste van appellanten (die de kosten voor de aanleg van de riolering waarop ook de riolering van geïntimeerden werd aangesloten, alleen hadden gedragen). Het hof van beroep te Luik wees de door appellanten ingestelde vordering uit ongerechtvaardigde verrijking echter af, omdat appellanten de kosten voor de aanleg van de riolering hadden gemaakt in uitvoering van een wettelijke verplichting, $\mathrm{nl}$. in uitvoering van de voorschriften van de verkavelingsvergunning. In casu was het inderdaad zo dat de verkavelingsvergunning aan de eigenaars van de verschillende loten van de verkaveling de verplichting oplegde om in te staan voor de aanleg van de riolering voor hun perceel. M.i. kan hieruit echter nog niet worden afgeleid dat het de kosten die hiertoe door een van de perceeleigenaars werden gemaakt en die naderhand ook aan een andere perceeleigenaar ten goede komen, onvergoed zouden moeten blijven. ${ }^{699}$

\subsubsection{Rechtvaardiging door een contract}

28. Een vordering uit ongerechtvaardigde verrijking is evenmin mogelijk indien een contract de verrijking van de verweerder ten koste van de eiser rechtvaardigt. ${ }^{700}$

29. Ook hier is enige verfijning op zijn plaats. Het is immers niet omdat de verrijking van de verweerder ten koste van de eiser in uitvoering van een contract plaatsvond, dat die verrijking automatisch gerechtvaardigd zou zijn. Dit is enkel het geval indien het de bedoeling van partijen was dat de verweerder voor deze verrijking geen vergoeding aan de eiser zou verschuldigd zijn.

Volgende voorbeelden kunnen dit illustreren:

697 Infra, paragraaf $3 \cdot 5$.

698 Luik 23 maart I989, JLMB I989, II87.

699 Wel kan er discussie bestaan of een vordering uit ongerechtvaardigde verrijking moet worden geweigerd omdat appellanten de riolering in hun eigen belang hadden aangelegd (zie infra, paragraaf 3.4.5).

700 H. De Page, Traité élémentaire de droit civil belge, III, Brussel, Bruylant, I967, 40C; R. Kruithof, H. Bocken, F. De Ly en B. De Temmerman, 'Verbintenissen. Overzicht van rechtspraak (I98II992)', TPR I994, (I7I) 620-62I, nr. 323; W. van Gerven, Verbintenissenrecht, Leuven, Acco, 2006, 290; P. Van Ommeslaghe, Droit des obligations, II, Sources des obligations (deuxième partie), Brussel, Bruylant, 2010, nr. 787 . 
- Stel dat een huurder met de eigenaar van het gehuurde goed had afgesproken dat hij bepaalde werken mocht uitvoeren. Op het einde van de huur komen deze werken bij wege van natrekking aan de eigenaar toe. ${ }^{70 r}$ Zoals hoger gezien, volstaan de wettelijke regels inzake natrekking echter niet als rechtvaardiging voor de verrijking die de verhuurder aldus ten koste van de huurder verkrijgt..$^{72}$ Verder is het ook niet omdat de huurder op basis van een overeenkomst met de eigenaar gerechtigd was de werken uit te voeren, dat de verrijking van de eigenaar ten koste van de huurder automatisch gerechtvaardigd zou zijn. De test ligt in de bedoeling van partijen: hebben zij gewild dat de verrijking van de eigenaar onvergoed zou blijven? Het antwoord op deze vraag luidt bevestigend wanneer het huurcontract bijvoorbeeld uitdrukkelijk bepaalde dat de werken zonder vergoeding aan de eigenaar zouden toekomen ${ }^{703}$ of wanneer de huurprijs op een laag bedrag werd vastgesteld, rekening houdende met de werken die de huurder aan het gehuurde goed zou uitvoeren. ${ }^{04}$ Indien daarentegen niet kan worden vastgesteld dat partijen de bedoeling hadden dat de door de huurder uitgevoerde werken onvergoed zouden blijven, is er geen juridische rechtvaardiging voor de verrijking van de eigenaar ten koste van de huurder. Indien de huurder in dat geval niet over een andere actiemogelijkheid beschikt, ${ }^{705 / 706} \mathrm{zal}$ hij bijgevolg een vordering uit ongerechtvaardigde verrijking tegen de eigenaar kunnen instellen. ${ }^{707}$

- Stel dat in een koopovereenkomst was bedongen dat de verkoper eigenaar van het verkochte goed zou blijven totdat de koper de volledige koopprijs had betaald. Indien de verkoper zich naderhand op dit eigendomsvoorbehoud beroept, is het niet uitgesloten dat de waarde van het teruggevorderde goed (bv. $€$ I.00o) het bedrag van de nog openstaande schuld van de koper (bv. € 6oo) overtreft. In dat geval wordt de verkoper door de terugname van het goed verrijkt ten koste van de koper, namelijk ten belope van het verschil tussen de waarde van het

70I Wanneer de huurovereenkomst hierover niets bepaalt, wordt de natrekking ten voordele van de verhuurder inderdaad uitgesteld tot het einde van de huurrelatie. Zie H. De Page en R. Dekkers, Traité élémentaire de droit civil belge, IV, Brussel, Bruylant, I972, nr. 688; T. Van Sinay, 'Bouwen op andermans grond', in: H. Vuye, P. Wéry, F. Van Neste en J. Kokelenberg (eds.), Eigendom, Brugge, die Keure, I996, 36r, nr. 8I

702 Supra, nr. 26.

703 Rb. Brussel I4 mei 2004, RW 2005-06, 792.

704 Rb. Brussel I september I998, RW I999-2000, I026, noot M. Neut.

705 Zoals de vordering waarover een huurder bij een handelshuurovereenkomst op grond van artikel 9 Handelshuurwet beschikt.

706 Aanvankelijk werd aangenomen dat door de huurder uitgevoerde werken onder de toepassing van artikel 555 BW vielen. Aldus had de verhuurder bij de beëindiging van de huur de keuze tussen de afbraak of het behoud van de werken mits vergoeding van het arbeidsloon. Thans is de dominante visie echter dat artikel $555 \mathrm{BW}$ in deze situatie geen toepassing kan vinden, omdat zij de specifieke situatie viseert waarin een bezitter van een onroerend goed door de eigenaar wordt uitgewonnen (H. De Page en R. Dekkers, Traité élémentaire de droit civil belge, IV, Brussel, Bruylant, I972, nr. 689; R. Kruithof, 'Le régime juridique des travaux réalisés par le preneur sur le fonds loué' (noot onder Cass. 23 april I965), RCJB I966, (55) 66-70, nrs. I7-20.

707 Rb. Ieper 6 mei I98I, RW I982-83, I395. Vgl. Cass. I8 april I99I, Arr. Cass. I990-9I, 839; T. Van Sinay, 'Bouwen op andermans grond', in: H. Vuye, P. Wéry, F. Van Neste en J. Kokelenberg (eds.), Eigendom, Brugge, die Keure, I996, 36r-362, nr. 82. 
teruggenomen goed en het bedrag van de nog openstaande schuld (in casu dus ten belope van $€ 400$ ). Deze verrijking is ongerechtvaardigd, aangezien partijen niet de bedoeling hadden dat de verkoper door de uitoefening van het eigendomsvoorbehoud ten koste van de koper zou worden verrijkt. Partijen hadden het eigendomsvoorbehoud van de koper immers louter als zekerheid bedoeld..$^{78}$ Om deze ongerechtvaardigde verrijking van de verkoper ten koste van de koper ongedaan te maken (in casu ten belope van $€ 400$ ), beschikt de koper dan ook over een vordering uit ongerechtvaardigde verrijking tegen de verkoper.

- Verder rijst in de praktijk regelmatig de vraag in welke mate een vordering uit ongerechtvaardigde verrijking mogelijk is na echtscheiding tussen echtgenoten die een huwelijkscontract met zuivere scheiding van goederen hadden gesloten. Te denken valt aan de situatie waarin de vrouw tijdens het huwelijk heeft meegewerkt in de eigen handelszaak van de man, waardoor die handelszaak een meerwaarde heeft gekregen. Deze meerwaarde valt dan uitsluitend toe aan de man als eigenaar van de handelszaak. ${ }^{709}$ Kan de vrouw hiervoor een compensatie vorderen op grond van de principes inzake ongerechtvaardigde verrijking? Rechtsleer en rechtspraak zijn hierover verdeeld. Volgens sommigen staat de keuze van partijen voor een huwelijkscontract met zuivere scheiding van goederen een dergelijke vordering in de weg. ${ }^{10}$ Hierboven is echter reeds opgemerkt dat het bestaan van een contractuele relatie tussen partijen een vordering uit ongerechtvaardigde verrijking niet hoeft uit te sluiten. Verder kan uit de wettelijke bepalingen inzake scheiding van goederen geenszins worden afgeleid dat het de bedoeling van de wetgever was dat de man geen vergoeding zou verschuldigd zijn voor de meerwaarde die zijn handelszaak door de inspanningen van zijn vrouw heeft verkregen. Indien ook niet uit de concrete bepalingen van het huwelijkscontract blijkt dat partijen de bedoeling hadden dat de meerwaarde die de handelszaak van de man door de inspanningen van zijn vrouw zou verkrijgen, onvergoed zou blijven, moet een vordering uit ongerechtvaardigde verrijking dan ook principieel worden toegelaten, ${ }^{71}$ doch slechts voor zover de door de vrouw geleverde inspanningen haar bijdrage in de lasten van het huwelijk overtreffen..$^{72}$ Artikel 22I, $\mathrm{I}^{\text {ste }}$ lid BW legt elke echtgenoot immers de verplichting op om naar zijn vermogen in de lasten van het huwelijk bij te dragen..$^{73}$ In de mate waarin de inspanningen van de vrouw kaderen in haar bijdrage in de lasten van het huwelijk, vindt de verrijking van de man ten koste van de vrouw bijgevolg haar rechtvaardiging

708 Vgl. E. Dirix, 'Functionele analyse van zekerheidsrechten', in: W. Pintens, A. Alen, E. Dirix en P. Senaeve (eds.), Vigilantibus Ius Scriptum. Feestbundel voor Hugo Vandenberghe, Brugge, die Keure, 2007, I20.

709 N. Torfs, 'De met scheiding van goederen gehuwde medewerkende echtgenoot: veroordeeld tot gratis werk?', TBBR 2006, (270) 27I, nr. I.3.2.

7 Io Zie bijvoorbeeld Antwerpen 30 november 2005, RW 2006-07, 882.

7 II Rb. Luik 8 januari I996, Rev. Trim. Dr. Fam. 1996, 572.

712 W. Pintens, C. Declerck en V. Allaerts, 'Huwelijksvermogensrecht. Overzicht van rechtspraak', TPR 20I0, (I383) I559-I560, nr. 253. Vgl. Luik 2 maart 2005, JT 2005, 557.

$7 \mathrm{I} 3$ Vgl. N. Torfs, 'De met scheiding van goederen gehuwde medewerkende echtgenoot: veroordeeld tot gratis werk?' TBBR 2006, (270) 274, nr. 2.2. 
in de wet, zodat de vrouw hiervoor geen vergoeding kan bekomen wegens ongerechtvaardigde verrijking.

30. Opdat een contract de verrijking van de verweerder ten koste van de eiser zou kunnen rechtvaardigen, is niet vereist dat dit contract tussen eiser en verweerder werd gesloten. Ook een contract gesloten tussen eiser of verweerder en een derde kan als juridische rechtvaardiging dienen. ${ }^{714}$ Het bestaan van een contract is immers een rechtsfeit dat aan eenieder kan worden tegengeworpen..$^{75}$ Ook wie geen partij was bij een contract, moet met andere woorden het bestaan en het gevolgen van het contract tussen partijen, erkennen..$^{716}$

Op verzoek van een huurder voert een aannemer werken uit aan een gehuurd goed. De huurder laat echter na de aannemer te betalen. Zoals hoger gezien, komen de werken op het einde van de huur bij wege van natrekking aan de eigenaar van het gehuurde goed toe. ${ }^{17}$ Aldus is de eigenaar verrijkt ten koste van de aannemer (die immers de werken heeft uitgevoerd zonder daarvoor vergoed te worden). Deze verrijking is echter niet ongerechtvaardigd indien het huurcontract (tussen verhuurder en huurder) uitdrukkelijk bepaalde dat de werken op het einde van de huur zonder enige vergoeding aan de verhuurder zouden toekomen. Aangezien het huurcontract als rechtsfeit aan de aannemer tegenwerpelijk is, dient de aannemer te erkennen dat de eigenaar geen vergoeding voor de werken verschuldigd kan zijn. Een vordering uit ongerechtvaardigde verrijking van de aannemer tegen de eigenaar zal bijgevolg niet slagen.

\subsubsection{Rechtvaardiging door de eigen wil van de eiser}

3I. Een verrijking van de verweerder ten koste van de eiser is niet ongerechtvaardigd indien zij haar oorsprong vindt in de eigen wil van de eiser. ${ }^{718}$

Het klassieke voorbeeld betreft de situatie waarin de eiser uit vrijgevigheid (animus donandi) handelde. ${ }^{19}$ Een man die aan zijn minnares een dure halsketting cadeau

7I4 B. De Coninck, 'A titre subsidiaire, l'enrichissement sans cause...', in: P. Wéry (ed.), La théorie générale des obligations. Suite, Luik, Editions Formation Permanente CUP, 2002, 63-64, nr. I2; W. van Gerven, Verbintenissenrecht, Leuven, Acco, 2006, 290.

7I5 Cass. 27 mei I909, Pas. I909, I, 272, concl. Terlinden; Cass. 9 maart I950, Arr. Verbr. I950, 46I, RCJB I952, 5, noot J. Dabin; Cass. 7 april I978, RW I978-79, I359.

7I6 I. Claeys, Samenhangende overeenkomsten en aansprakelijkheid, Antwerpen, Intersentia, 2003, nr. Io6; W. van Gerven, Verbintenissenrecht, Leuven, Acco, 2006, 223.

7 I7 Supra, nr. 29.

7I8 H. De Page, Traité élémentaire de droit civil belge, III, Brussel, Bruylant, I967, 40C; W. van Gerven, Verbintenissenrecht, Leuven, Acco, 2006, 290; P. Van Ommeslaghe, Droit des obligations, II, Sources des obligations (deuxième partie), Brussel, Bruylant, 2010, nr. 788.

7I9 Rb. Namen 7 juni I983, Rec. Gén. Enr. Not. I984, 259; H. De Page, Traité élémentaire de droit civil belge, III, Brussel, Bruylant, I967, nr. 40C; C. Marr, 'L'enrichissement sans cause. Un fondement d'équité sous une apparente rigeur...', in: S. Stijns en P. Wéry (eds.), De bronnen van niet-contractuele verbintenissen, Brugge, die Keure, 2007, 222, nr. I5; W. van Gerven, Verbintenissenrecht, Leuven, Acco, 2006, 290; P. Van Ommeslaghe, Droit des obligations, II, Sources des obligations (deuxième partie), Brussel, Bruylant, 20Io, nr. 788 . 
geeft, kan deze later dus niet terugvorderen op grond van de principes inzake ongerechtvaardigde verrijking.

32. Hoewel hierover in de huidige stand van het recht wat verwarring lijkt te bestaan, is het niet omdat de eiser vrijwillig handelde, dat de verrijking van de verweerder door de eigen wil van de eiser wordt gerechtvaardigd. Vereist is dat het de wil van de eiser was dat de verrijking aan de verweerder zou toekomen, zonder dat deze laatste daarvoor een vergoeding zou moeten betalen (of enige andere tegenprestatie zou moeten leveren).

Een cassatiearrest van I9 januari 2009 illustreert dit. ${ }^{720}$ Een vennootschap had aan een gerechtsdeurwaarder een bedrag betaald ter voldoening van een persoonlijke schuld van haar bestuurder. Enige tijd later ging de vennootschap failliet. Vervolgens vorderden de curatoren het door de vennootschap aan de gerechtsdeurwaarder betaalde bedrag wegens ongerechtvaardigde verrijking terug van de bestuurder. Het hof van beroep te Antwerpen willigde deze vordering in. Het oordeelde dat de vennootschap noch een eigen schuld wilde betalen, noch uit vrijgevigheid handelde, maar slechts hulp heeft willen bieden aan haar bestuurder met de vanzelfsprekende gedachte dat deze de voorgeschoten gelden zou terugbetalen. Het Hof van Cassatie sloot zich bij deze redenering aan. Het Hof overwoog dat 'indien de tijdelijke terbeschikkingstelling van de gelden wel een oorzaak had, namelijk de hulpvaardigheid van de vennootschap, deze laatste niet de wil had een vermogensverschuiving tot stand te brengen, zodat het bedrag van de tijdelijk ter beschikking gestelde gelden dan ook op grond van het algemeen rechtsbeginsel van de verrijking zonder oorzaak mocht worden teruggevorderd.'

33. De vraag rijst of een verrijking van de verweerder door de eiser ongerechtvaardigd is indien zij plaatsvond met een bepaald doel dat uiteindelijk niet werd bereikt of met een bepaalde verwachting die uiteindelijk niet werd ingelost.

Volgens het DCFR is in die omstandigheden inderdaad sprake van een ongerechtvaardigde verrijking van de verweerder ten nadele ${ }^{721}$ van de eiser, mits aan twee voorwaarden is voldaan. Vooreerst is vereist dat de verweerder kennis had (of redelijkerwijze geacht kan worden kennis te hebben gehad) van het doel of de verwachting van de eiser. Bovendien moet de verweerder aanvaard hebben (of redelijkerwijze verondersteld worden te hebben aanvaard) dat hij de verrijking zou moeten teruggeven indien het doel niet werd bereikt of indien de verwachting niet werd ingelost. ${ }^{22}$

720 Cass. I9 januari 2009, RW 2009-Io, I084, noot E. Nordin.

72 I Supra, nr. I4.

722 'Art. VII. - 2:101 (4) DCFR: Circumstances in which an enrichment is unjustified

(4) An enrichment is also unjustified if:

(a) the disadvantaged person conferred it:

(i) for a purpose which is not achieved; or

(ii) with an expectation which is not realised;

(b) the enriched person knew of, or could reasonably be expected to know of, the purpose or expectation; and 
Als voorbeeld verwijst de toelichting bij het DCFR naar de situatie waarin een man meehelpt met de bouw van een woning op de grond van de verloofde van zijn dochter, in de gedachte dat die woning na het huwelijk als gezinswoning voor het jonge paar zou dienen. Kort voor het geplande huwelijk gaat het koppel echter uiteen. Volgens het DCFR beschikt de vader in dat geval over een vordering uit ongerechtvaardigde verrijking tegen de ex-verloofde van zijn dochter. De verrijking van de ex-verloofde door de vader vond immers plaats met de verwachting dat de woning als gezinswoning voor zijn dochter zou dienen. Bovendien mocht de ex-verloofde redelijkerwijze verondersteld worden te weten dat de inspanningen van de vader om die reden werden geleverd. Ten slotte mag de ex-verloofde ook redelijkerwijze verondersteld worden te hebben aanvaard dat hij de verkregen verrijking zou moeten teruggeven indien, zoals in casu, de verwachtingen van de vader niet werden ingelost.

Is ook naar Belgisch recht een vordering uit ongerechtvaardigde verrijking in die omstandigheden mogelijk? Om deze vraag te beantwoorden, moet, zoals hoger gezien, onderzocht worden of het de wil van de vader was dat de verrijking aan de ex-verloofde van zijn dochter zou toekomen, zonder dat deze daarvoor enige vergoeding zou verschuldigd zijn..$^{23}$

In casu lijkt het inderdaad de wil van de vader geweest te zijn dat de verrijking aan de verloofde van zijn dochter zou toekomen, maar is het evenzeer zijn wil geweest dat zijn dochter ook van deze verrijking zou profiteren (namelijk doordat ook zij de woning zou betrekken). Bijgevolg is het inderdaad verdedigbaar dat het niet de wil van de vader was dat de verrijking in de gegeven omstandigheden onvergoed aan de ex-verloofde van zijn dochter zou toekomen, zodat hij over een vordering uit ongerechtvaardigde verrijking tegen de ex-verloofde van zijn dochter beschikt.

Er moet evenwel worden nagegaan of een dergelijke oplossing niet op gespannen voet komt te staan met het cassatiearrest van $\mathrm{I} 2$ december $2008,{ }^{724}$ waarin het Hof van Cassatie besliste dat gebeurtenissen die de doorslaggevende beweegreden van een schenking doorkruisen, de geldigheid van die schenking niet aantasten (voor zover wordt aangenomen dat deze rechtspraak niet alleen geldt voor schenkingen, maar voor alle overeenkomsten om niet). Er zou immers geargumenteerd kunnen worden dat tussen de vader en de ex-verloofde van zijn dochter een overeenkomst tot stand was gekomen op basis waarvan de vader om niet had meegeholpen met de bouw van de woning op de grond van de ex-verloofde van zijn dochter. Hierbij had de vader als doorslaggevende beweegreden dat de woning als gezinswoning voor zijn dochter zou dienen. Nu deze doorslaggevende beweegreden zich niet verwerkelijkt, zou dit bij analoge toepassing van voormeld arrest van 12 december 2008 , geen

(c) the enriched person accepted or could reasonably be assumed to have accepted that the enrichment must be reversed in such circumstances.'

723 Vgl. supra, nr. 32.

724 Cass. I2 december 2008, RW 2008-09, I69o, noot R. Barbaix. 
invloed kunnen hebben op de geldigheid van de overeenkomst om niet die per hypothese tussen de vader en de ex-verloofde van zijn dochter tot stand was gekomen.

In zijn arrest van 12 december 2008 merkt het Hof van Cassatie echter ook nog op dat een geldige schenking wel kan worden 'herroepen' 'wegens het niet vervullen van een voorwaarde of wegens ondankbaarheid. ${ }^{725}$ Mutatis mutandis moet dan ook een overeenkomst om niet kunnen worden 'herroepen' bij niet vervulling van een voorwaarde. Indien men uit de concrete omstandigheden gaat afleiden dat de vader een overeenkomst om niet met de ex-verloofde van zijn dochter had gesloten, kan men er niet om heen dat dit gebeurde opdat de woning als gezinswoning voor zijn dochter zou dienen. Aldus valt te verdedigen dat de overeenkomst om niet werd gesloten onder de ontbindende voorwaarde ${ }^{726}$ dat de woning als gezinswoning voor de dochter zou dienen. $\mathrm{Nu}$ deze voorwaarde niet in vervulling is gegaan, kan de vader de overeenkomst om niet dan ook 'herroepen', waardoor de overeenkomst niet langer als rechtvaardiging voor de verrijking van de ex-verloofde van zijn dochter kan dienen.

\subsubsection{Speculatie}

34. De vordering uit ongerechtvaardigde verrijking moet worden afgewezen indien de eiser uit speculatief oogmerk handelde. ${ }^{727} \mathrm{Wie}$ speculeert op een bepaald resultaat dat hij hoopt te bereiken, weet immers dat het risico bestaat dat dit resultaat niet wordt bereikt. Dit is een risico dat aan elke operatie met een kanselement kleeft. ${ }^{728}$

Stel dat een zakenman een potentiële klant op een diner in een exclusief restaurant trakteert, in de hoop met hem een lucratieve overeenkomst te sluiten. Als het naderhand toch niet tot een overeenkomst komt, kan de zakenman de restaurantkosten niet op grond van ongerechtvaardigde verrijking van zijn tafelgenoot terugvorderen. De zakenman handelde immers uit speculatief oogmerk.

Om dezelfde reden kan ook wie auto's wast op de parking van een grootwarenhuis in de hoop hiervoor een beloning te ontvangen, zich niet op de principes inzake ongerechtvaardigde verrijking beroepen indien de verhoopte beloning uitblijft.

725 Cass. I2 december 2008, RW 2008-o9, I69o, noot R. Barbaix.

726 Een (ontbindende) voorwaarde moet immers niet expliciet worden bedongen. Het volstaat dat het bestaan van de voorwaarde vaststaat. Zie M. Van Quickenborne, 'Voorwaarde', in: E. Dirix en A. Van Oevelen (eds.), Bijzondere Overeenkomsten. Artikelsgewijze commentaar met overzicht van rechtspraak en rechtsleer, Antwerpen, Kluwer, 2005, nr. I25.

727 Rb. Dinant I2 oktober I988, Rev. Not. B. I989, 200; Rb. Namen 7 juni I983, Rec. Gén. Enr. Not. I984, 259; H. De Page, Traité élémentaire de droit civil belge, III, Brussel, Bruylant, I967, 40C; P. Van Ommeslaghe, Droit des obligations, II, Sources des obligations (deuxième partie), Brussel, Bruylant, 20I0, nr. 788.

728 A. De Bersaques, 'Le caractère subsidiaire de l'actio de in rem verso' (noot onder Gent 29 januari I955), RCJB I957, (I20) I28, nr. I7. 
35. In de rechtspraak en rechtsleer wordt deze zienswijze echter niet steeds op consequente wijze doorgetrokken.

Zo was er een geval waarin een genealoog op eigen intiatief de erfgenamen van een overledene had opgespoord, in de hoop van hen een vergoeding te ontvangen in ruil voor nadere informatie over de nalatenschap waarop zij aanspraak konden maken. Enkele erfgenamen weigerden echter een dergelijke vergoeding te betalen. Echter, doordat de genealoog hen erop had attent gemaakt dat zij recht hadden op een hun tot dan toe onbekend gebleven nalatenschap (zonder evenwel de naam van de erflater te noemen), waren deze erfgenamen er zelf in geslaagd te weten te komen wie de erflater was. Hierop stelde de genealoog een vordering uit ongerechtvaardigde verrijking tegen deze erfgenamen in. Hoewel de genealoog duidelijk uit speculatief oogmerk handelde, willigde het hof van beroep te Brussel deze vordering toch in. ${ }^{729}$

\subsubsection{Eigenbelang}

36. Een vordering uit ongerechtvaardigde verrijking is evenmin mogelijk wanneer de eiser de behartiging van zijn eigen belangen nastreefde ${ }^{73^{\circ}}$ en de verrijking van de verweerder hier een niet-bedoeld gevolg van is..$^{7{ }^{31}}$ De verrijking van de verweerder ten koste van de eiser vindt in dat geval haar rechtvaardiging in de beslissing die de eiser in zijn eigen belang heeft genomen, ${ }^{732}$ waarbij hij ervan uitging dat de gemaakte kosten of geleverde inspanningen definitief te zijnen laste zouden vallen.

Stel dat de eigenaar van een rij krotwoningen deze volledig renoveert, waardoor ook de andere woningen in de straat worden opgewaardeerd. Aangezien de eigenaar bij zijn beslissing om de woningen te renoveren, de behartiging van zijn eigen belangen nastreefde, beschikt hij niet over een vordering uit ongerechtvaardigde verrijking tegen de huiseigenaars die door de renovatie de waarde van hun eigen huis hebben zien stijgen..$^{733}$

\subsubsection{Uitvoering van een natuurlijke verbintenis}

37. De verrijking van de verweerder ten koste van de eiser is ook niet ongerechtvaardigd indien zij op de uitvoering van een natuurlijke verbintenis berust. ${ }^{734}$ Dit wordt bevestigd door artikel I235, $2^{\text {de }}$ lid BW, dat bepaalt dat geen terugvordering

729 Brussel 26 februari i969, JT i970, I36, noot S. Levy.

730 P. Van Ommeslaghe, Droit des obligations, II, Sources des obligations (deuxième partie), Brussel, Bruylant, 20Io, nr. 788.

73I H. De Page, Traité élémentaire de droit civil belge, III, Brussel, Bruylant, I967, nr. 40C.

732 W. van Gerven, Verbintenissenrecht, Leuven, Acco, 2006, 290-29I.

733 Vgl. Luik II maart I97I, JT I97I, 29I: 'Attendu que la plus-value éventuellement acquise par l'immeuble de l'intimé, en suite du parachèvement de la construction voisine de l'appellante, ne constitue pas un enrichissement sans cause, par rapport à cette dernière, puisque celle-ci ne s'en trouve pas corrélativement appauvrie, les sommes qu'elle a dépensées en l'occurrence n'étant que la suite de sa détermination de gérer ses propres intérêts.'

734 W. van Gerven, Verbintenissenrecht, Leuven, Acco, 2006, 290; P. Van Ommeslaghe, Droit des obligations, II, Sources des obligations (deuxième partie), Brussel, Bruylant, 20Io, nr. 788. 
kan plaatshebben ten opzichte van natuurlijke verbintenissen die men vrijwillig voldaan heeft.

38. Bij de beëindiging van een feitelijke samenwoningsrelatie rijst regelmatig de vraag of de ene partner op grond van de principes inzake ongerechtvaardigde verrijking een vergoeding kan bekomen voor investeringen die hij in het onroerend goed van de andere partner heeft gedaan (bv. door verbouwingswerken aan dat onroerend goed te financieren). Op grond van de regels inzake natrekking komt de meerwaarde die het onroerend goed door deze investeringen heeft gekregen, immers uitsluitend toe aan de partner-eigenaar van het onroerend goed. Zoals hoger gezien, impliceren de wettelijke regels inzake natrekking echter geenszins dat de verrijking die de partner-eigenaar aldus ten koste van de investerende partner verkrijgt, onvergoed zou moeten blijven.

Aanvankelijk stonden rechtspraak en rechtsleer weigerachtig tegenover de toekenning van een vergoeding aan de investerende partner. ${ }^{735}$ Gesteld werd dat de investerende partner handelde uit vrijgevigheid, ${ }^{73^{6}}$ dan wel met een speculatief oogmerk of in zijn eigen belang, ${ }^{737}$ zodat een vordering uit ongerechtvaardigde verrijking om die reden was uitgesloten.

Deze zienswijze kan echter niet overtuigen. Doorgaans zal de investerende partner de investeringen hebben gedaan met de bedoeling hiervan samen met zijn partner te genieten, en dus niet uit vrijgevigheid of uitsluitend in zijn eigen belang. Verder is het ook niet omdat een partner investeringen heeft gedaan in het kader van de uitbouw van een gezamenlijke toekomst met zijn partner, dat deze handelwijze speculatief zou zijn.

Dit neemt niet weg dat het beleidsmatig vaak niet wenselijk is dat ex-partners na de beëindiging van hun feitelijke samenlevingsrelatie allerlei vergoedingen beginnen opeisen voor kosten die zij in het kader van de feitelijke samenleving hebben gemaakt. Toch zijn er situaties waarin dit anders voorkomt, bijvoorbeeld wanneer de ene partner de bouw van een woning op het onroerend goed van de andere partner helemaal alleen heeft gefinancierd.

Om nu te bepalen in welke gevallen de investerende partner aanspraak moet kunnen maken op een vergoeding, kan een beroep op de figuur van de natuurlijke verbintenis een uitkomst bieden. Het Belgische recht lijkt immers steeds meer te evolueren in de zin dat feitelijk samenwonende partners een natuurlijke verbintenis

735 F. Baudoncq en V. Guffens, 'Bouwen op andermans goed in het specifieke geval van concubinaat', T. Not. 2003, (318) 335-336, nr. 36; H. Casman, 'Vereffening-verdeling na beëindiging van de relatie tussen ongehuwde samenwoners', in: X (ed.), Familie op maat, Mechelen, Kluwer, 2005, 36I-362; Y.-H. Leleu (ed.), Droit patrimonial des couples, Luik, Anthemis, 20II, nr. I23.

736 Antwerpen $\mathrm{I}_{3}$ april I987, Rev. Not. B. I988, 203.

737 Gent 20 november 2008, TBBR 20II, 39, noot S. Bouly; Rb. Veurne 27 mei 2004, TGR 2004, Igo. 
hebben om bij te dragen in de lasten van de samenwoning. ${ }^{.3^{8}}$ Wat een partner in uitvoering van deze natuurlijke verbintenis heeft gepresteerd, kan hij dan ook niet wegens ongerechtvaardigde verrijking terugvorderen. ${ }^{739}$ In de mate waarin de kosten of inspanningen die een partner heeft gedaan, de uitvoering van deze natuurlijke verbintenis te boven gaan, is echter wel een vordering uit ongerechtvaardigde verrijking mogelijk..$^{70}$

In de rechtspraak lijkt deze opvatting alvast steeds meer weerklank te vinden. ${ }^{74}$

Een man had voor ongeveer $€ 8.400$ herstellingswerken laten uitvoeren aan de woning van de vrouw met wie hij samenleefde. Het betrof het injecteren van de muren tegen vocht en het vervangen van de ramen. Het hof van beroep te Brussel oordeelde dat de kosten voor deze herstellingswerken de normale huishouduitgaven niet te boven gingen, rekening houdende met het feit dat de man gedurende drie jaar in de gemeubelde woning van de vrouw had gewoond en met het feit dat de vrouw de woning alleen afbetaalde. De door de man ingestelde vordering uit ongerechtvaardigde verrijking werd dan ook afgewezen..$^{742}$

Ook het hof van beroep te Luik oordeelde dat geen vordering uit ongerechtvaardigde verrijking openstond voor diverse werken van beperkte omvang (o.a. automatisatie garagepoort, leggen van parket) die een man had laten uitvoeren in de woning van de vrouw met wie hij samenwoonde. Volgens het hof kaderden de kosten die de man hiertoe had gemaakt, immers in de uitvoering van zijn natuurlijke verbintenis tot bijdrage in de lasten van de samenleving. ${ }^{743}$

Het hof van beroep te Gent kende daarentegen wel een vergoeding toe aan een man die kosten en inspanningen had gedaan voor de bouw van een garage en een tuinhuis voor de woning van de vrouw met wie hij samenwoonde. In casu had de man gedurende de samenleving een maandelijkse vergoeding van $€ 500$ betaald als deelname in de kosten van de huishouding. De kosten en inspanningen die de man daarnaast nog had gedaan voor de bouw van de garage en het tuinhuis, konden dan

738 Bergen 25 oktober I999, Rev. trim. dr. fam. 2000, 84; Luik 3 september 2008, Rev. trim. dr. fam. 20Io, 328; Rb. Oudenaarde ig september 2005, RABG 2006, 774; J. Du Mongh, V. Allaerts en I. Samoy, 'Overzicht van rechtspraak (2000-2007) - de feitelijke samenwoning', T. Fam. 2008, (4) 8 , nr. Io; P. Senaeve, 'De onderhoudsverplichting tussen wettelijk samenwonenden en tussen concubinerenden', in: P. Senaeve (ed.), Onderhoudsgelden, Leuven, Acco, 200I, I67-I68, nr. 249; K. Willems, De natuurlijke verbintenis, Brugge, die Keure, 200I, nr. 300.

739 J. Du Mongh, V. Allaerts en I. Samoy, 'Overzicht van rechtspraak (2000-2007) - de feitelijke samenwoning', T. Fam. 2008, (4) 8, nr. Io.

740 W. Pintens, C. Declerck, J. Du Mongh en K. Vanwinckelen, Familiaal vermogensrecht, Antwerpen, Intersentia, 20I0, nr. 969; K. Willems, De natuurlijke verbintenis, Brugge, die Keure, 20II, nr. 303.

74I Brussel 27 februari 200I, RW 200I-02, 844; Gent 27 oktober 2009, TGR 20I0, 86; Luik 3 september 2008, Rev. trim. dr. fam. 2010, 328; Rb. Luik 2 oktober 1989, Rec. Gén. Enr. Not. 1990, 387; Rb. Nijvel 22 april 2009, Rev. trim. dr. fam. 2010, 347. Vgl. ook Gent 23 maart I999, TBBR 2000, 3II. Zie ook Y.-H. Leleu (ed.), Droit patrimonial des couples, Luik, Anthemis, 20II, nr. I23.

742 Brussel 27 februari 200I, RW 200I-02, 844.

743 Luik 3 september 2008, Rev. trim. dr. fam. 20I0, 328. 
ook niet als (de uitvoering van zijn natuurlijke verbintenis tot) bijdrage in de kosten van de samenleving worden gezien. ${ }^{74}$

Ook de rechtbank van eerste aanleg te Luik kende op grond van de principes inzake ongerechtvaardigde verrijking een vergoeding toe aan een man die de installatie van centrale verwarming, een nieuwe badkamer en de vernieuwing van de elektriciteit in de eigen woning van de vrouw had gefinancierd. Volgens de rechtbank gingen de kosten die de man aldus had gemaakt, de bijdrage in de kosten van het samenleven immers ver te buiten. ${ }^{745}$

39. Een gelijkaardige problematiek doet zich voor in gevallen waarin een persoon vrijwillig de zorg van een andere persoon op zich neemt. Te denken valt aan de situatie waarin een persoon een oud of ziek familielid in huis heeft genomen of heeft verzorgd, of aan de situatie waarin een kind niet door zijn ouders, maar door een ander familielid of door een derde wordt opgevoed..$^{46}$

Ook in deze gevallen is de rechtspraak eerder terughoudend om op grond van de principes inzake ongerechtvaardigde verrijking een vergoeding toe te kennen aan de persoon die de zorg heeft verleend (hierna: de zorgverstrekker) en die hierdoor werd verarmd.

In ieder geval moet een vordering uit ongerechtvaardigde verrijking worden afgewezen indien de zorgverstrekker met speculatief oogmerk handelde, ${ }^{747}$ bijvoorbeeld in de hoop om van de verzorgde persoon een schenking of legaat te ontvangen.

Voorts kan van een ongerechtvaardigde verrijking evenmin sprake zijn indien de zorgverstrekker uit vrijgevigheid handelde, ${ }^{74^{8}}$ dat wil zeggen met de ingesteldheid dat de geleverde prestaties onvergoed zouden blijven.

Het komt echter regelmatig voor dat de zorgverstrekker op het ogenblik waarop hij de prestaties leverde, noch uit speculatief oogmerk, noch uit vrijgevigheid handelde. Dit betekent echter nog niet dat hij steeds aanspraak zou kunnen maken op een vergoeding op grond van de principes inzake ongerechtvaardigde verrijking. Ook hier zullen de door de zorgverstrekker geleverde prestaties immers dikwijls kunnen worden gezien als de uitvoering van een natuurlijke verbintenis tot bijstand en zorg voor een hulpbehoevend familielid. In dat geval zal slechts een vergoeding wegens ongerechtvaardigde verrijking mogelijk zijn indien en in de mate waarin de door de zorgverstrekker geleverde prestaties de uitvoering van deze natuurlijke verbintenis

744 Gent 27 oktober 2009, TGR 20I0, 86.

745 Rb. Luik 2 oktober I989, Rec. Gén. Enr. Not. I990, 387.

746 B. Wylleman, 'Vergoeding van prestaties voor familie of vrienden op basis van zaakwaarneming of vermogensverschuiving zonder oorzaak' (noot onder Brussel 3 juni 1996), AJT 1996-97, (329) 329 , nr. I.

747 Vgl. supra, nr. 34 .

748 Vgl. supra, nr. 3 I. 
te boven gaan. ${ }^{74}$ Dit is bijvoorbeeld het geval wanneer een dochter haar zieke moeder gedurende de laatste maanden van haar leven bij haar heeft laten inwonen en permanent heeft verzorgd, zonder daar enige vergoeding voor te ontvangen..$^{70}$

\subsection{Subsidiariteit}

40. Anders dan bijvoorbeeld in het Nederlandse of Duitse recht of in het DCFR, heeft de vordering uit ongerechtvaardigde verrijking naar Belgisch recht een subsidiair karakter. Zoals hoger toegelicht, is dit te verklaren doordat de vordering uit ongerechtvaardigde verrijking in het Belgische recht - anders dan in het Nederlandse of Duitse recht of in het DCFR - geen uitdrukkelijke wettelijke grondslag heeft, maar 'slechts' op een algemeen rechtsbeginsel steunt. Hieruit volgt dat de vordering uit ongerechtvaardigde verrijking naar Belgisch recht enkel kan worden aangewend om leemtes in de wet op te vullen. Aldus kan de vordering uit ongerechtvaardigde verrijking enkel worden ingezet indien de wet geen enkele andere actiemogelijkheid aan de eiser ter beschikking stelt..$^{75}$

4I. In de huidige stand van het recht heerst soms verwarring tussen de vereiste van de afwezigheid van juridische rechtvaardiging ${ }^{752}$ en de subsidiariteitsvereiste. ${ }^{753}$ Toch bestaat een duidelijk verschil tussen beide.

De vereiste van de afwezigheid van een juridische rechtvaardiging beoogt te vermijden dat een vordering uit ongerechtvaardigde verrijking wordt ingesteld wanneer de verrijking van de verweerder ten koste van de eiser in de ogen van het recht gerechtvaardigd is. ${ }^{754}$

Pas wanneer vaststaat dat de verrijking van de verweerder ten koste van de eiser ongerechtvaardigd is, strekt de subsidiariteitsvereiste ertoe te vermijden dat een vordering uit ongerechtvaardigde verrijking zou worden ingesteld wanneer de wet een vordering op een andere grondslag mogelijk maakt.

42. Het Hof van Cassatie is van oordeel dat het subsidiaire karakter van de vordering uit ongerechtvaardigde verrijking onder andere meebrengt dat deze vordering moet worden afgewezen indien de eiser over een vordering op een andere rechtsgrond

749 Vgl. de inmiddels vaste rechtspraak van de Franse Cour de Cassation dat een vordering uit ongerechtvaardigde verrijking mogelijk is wanneer de door een kind aan zijn ouders geleverde zorg en bijstand de grenzen van de 'piétéfiliale' te boven gaat. Zie Cass. 23 januari 200I, nr. 98-22.937; Cass. fr. 3 november 2004, nr. oI-I5.I76; Cass. fr. 26 januari 20II, nr. 09-70.658. Vgl. ook K. Willems, De natuurlijke verbintenis, Brugge, die Keure, 20II, nrs. 358-363.

750 Brussel 3 juni 1996, AJT I996-97, 328, noot B. Wylleman.

75 I Supra, nr. 6.

752 Supra, paragraaf $3 \cdot 4$.

753 Vgl. R. Kruithof, H. Bocken, F. De Ly en B. De Temmerman, 'Verbintenissen. Overzicht van rechtspraak (I98I-I992)', TPR I994, (I7I) 624, nr. 328.

754 Supra, nr. 2 I. 
beschikte, maar deze heeft laten tenietgaan 755 (bijvoorbeeld door verval of door verjaring).

Ter illustratie kan worden verwezen naar een cassatiearrest van 25 maart I994. Naar aanleiding van een verkeersongeval had een rechter een WAM-verzekeraar samen met zijn verzekerde en met een derde-aansprakelijke in solidum veroordeeld om de schade van het slachtoffer te vergoeden. Nadat de WAM-verzekeraar de schade van het slachtoffer integraal had vergoed, liet hij na zijn subrogatoire vordering tegen de derde-aansprakelijke tijdig in te stellen. Hierop stelde de WAM-verzekeraar een vordering uit ongerechtvaardigde verrijking tegen de derde-aansprakelijke in, om alsnog nog een deel van de aan het slachtoffer betaalde vergoeding te kunnen recupereren. Deze vordering werd echter afgewezen. Volgens het Hof van Cassatie '[belet] het subsidiaire karakter van de vordering die op verrijking zonder oorzaak steunt, dat deze vordering wordt aangenomen wanneer, zoals te dezen, de partij een andere vordering, die zij heeft laten tenietgaan, kon instellen.' ${ }^{756}$

Is een beroep op de subsidiariteitsvereiste wel nodig om een vordering uit ongerechtvaardigde verrijking af te wijzen in gevallen waarin de eiser de vordering waarover hij beschikte, door verval of verjaring heeft laten tenietgaan? Naar Nederlands voorbeeld ${ }^{757}$ zou immers ook - en m.i. beter - kunnen worden geargumenteerd dat in deze gevallen de verrijking van de verweerder niet langer ongerechtvaardigd is. Uit de strekking van de wettelijke bepalingen inzake verjaring en verval blijkt immers dat het de bedoeling van de wetgever was dat de verweerder de verrijking zonder vergoeding zou mogen behouden indien de eiser de vordering waarover hij beschikte, door verjaring of verval heeft laten tenietgaan.

43. Verder lijkt het in België de dominante visie te zijn dat de subsidiariteitsvereiste enkel in de verhouding tussen eiser en verweerder speelt. ${ }^{75^{8}}$ Een vordering uit ongerechtvaardigde verrijking is bijgevolg niet mogelijk zodra de eiser over een andere vordering tegen de verweerder beschikt, maar is niet uitgesloten indien de eiser over een vordering tegen een derde beschikt.

Bepaalde rechtsleer voegt hier nog aan toe dat, wanneer de eiser over een vordering tegen een derde beschikt, hij slechts een vordering uit ongerechtvaardigde verrijking tegen de verweerder kan instellen indien de vordering tegen de derde is

755 Cass. II september I969, Arr. Verbr. I970, 36; Cass. 25 maart I994, RW I996-97, 45, noot A. Van Oevelen.

756 Cass. 25 maart 1994, RW I996-97, 45, noot A. Van Oevelen.

757 C. Asser, A. S. Hartkamp en C. H. Sieburgh, Verbintenissenrecht. De verbintenis uit de wet, in: Mr. C. Asser's handleiding tot de beoefening van het Nederlands burgerlijk recht, 6-IV, Deventer, Kluwer, 20II, nr. 467; J. Spier, T. Hartlief, G. E. Van Maanen en R. D. Vriesendorp, Verbintenissen uit de wet en schadevergoeding, in: Studiereeks burgerlijk recht, Deventer, Kluwer, 2009, nr. 3 I6.

758 H. De Page, Traité élémentaire de droit civil belge, III, Brussel, Bruylant, I967, nr. 33; E. Dirix en A. Van Oevelen, 'Kroniek van het verbintenissenrecht (I985-I992) (eerste deel)', RW I992-93, (I209) I262, nr. 99. 
teloorgegaan of ondoeltreffend is geworden zonder dat aan de eiser iets te verwijten valt. Dit is bijvoorbeeld het geval wanneer de derde insolvabel is geworden..$^{759}$

Opnieuw valt te denken aan de situatie waarin een aannemer op vraag van een huurder werken uitvoert aan het gehuurde goed. De huurder laat echter na de aannemer te betalen. Op het einde van de huur komen de aan het gehuurde goed uitgevoerde werken op grond van natrekking aan de eigenaar van het verhuurde goed toe. Aldus wordt de eigenaar verrijkt ten koste van de aannemer, die de werken immers heeft uitgevoerd zonder daarvoor vergoed te worden. Deze verrijking van de eigenaar is in principe niet gerechtvaardigd, ${ }^{760}$ aangezien uit de wettelijke bepalingen inzake natrekking niet kan worden afgeleid dat de verrijking die de eigenaar van een goed bij wege van natrekking verkrijgt, onvergoed zou moeten blijven. ${ }^{7 \mathrm{r}}$ Verder kan ook voor de verarming van de aannemer geen rechtvaardiging worden gevonden. De aannemer had immers met de huurder afgesproken dat hij de werken in ruil voor een bepaalde vergoeding zou uitvoeren. Indien de dominante visie wordt gevolgd, verhindert de omstandigheid dat de aannemer over een contractuele vordering tegen de huurder beschikt, niet dat de aannemer een vordering uit ongerechtvaardigde verrijking tegen de eigenaar instelt (evenwel volgens sommigen slechts wanneer de huurder insolvabel is).

Dit resultaat valt echter moeilijk te verzoenen met ons uitgangspunt dat een vordering uit ongerechtvaardigde verrijking naar Belgisch recht enkel kan worden ingezet om leemten in de wet op te vullen. In casu is er helemaal geen leemte in de wet. De wet verschaft de aannemer immers een contractuele vordering tegen de huurder.

Bovendien zal het belang van het instellen van een vordering uit ongerechtvaardigde verrijking ingeval de eiser over een andere vordering tegen een derde beschikt, in de praktijk vooral tot uiting komen indien er een situatie van samenloop van schuldeisers op het vermogen van die derde is ontstaan (bv. bij faillissement van die derde). In dat geval zal een vordering uit ongerechtvaardigde verrijking echter niet kunnen worden toegelaten indien de toewijzing ervan de andere schuldeisers van de derde zou benadelen (wat meestal het geval zal zijn). Er kan inderdaad niet worden aanvaard dat een vordering uit ongerechtvaardigde verrijking afbreuk zou doen aan artikel 8 van de Hypotheekwet, op grond waarvan schuldeisers die verhaal zoeken op het vermogen van hun gemeenschappelijke debiteur, in principe gelijk moeten worden behandeld (tenzij er tussen hen wettige redenen van voorrang zouden bestaan). Uit de rechtspraak van het Hof van Cassatie volgt immers dat een algemeen rechtsbeginsel - hier: het beginsel dat niemand zich ten koste van een ander

759 P. Maes, 'Ongegronde vermogensverschuivingen en driepartijenverhoudingen', TPR 20Io, (I87) 210, nr. 22.

760 Tenzij uit het huurcontract zou blijken dat het de bedoeling van partijen (huurder en verhuurder) was dat de werken op het einde van de huur kosteloos aan de verhuurder zouden toekomen (vgl. supra, nr. 29).

76r Vgl. supra, nrs. 26 en 29. 
ongerechtvaardigd mag verrijken - in geen geval kan worden toegepast wanneer die toepassing onverenigbaar is met de ondubbelzinnige wil van de wetgever. ${ }^{762}$

Indien er, in het hierboven beschreven voorbeeld, een situatie van samenloop van schuldeisers op het vermogen van de huurder zou zijn ontstaan (bv. door faillissement van de huurder), zou de toekenning van een vordering uit ongerechtvaardigde verrijking aan de aannemer tegen de eigenaar impliceren dat de aannemer aan deze samenloop kan ontsnappen, ten nadele van de andere schuldeisers van de huurder. De betaling van de eigenaar aan de aannemer zou het onderpand van de samenlopende schuldeisers immers doen verkleinen, aangezien zij de schuldvordering van de huurder op de eigenaar ten belope van het betaalde bedrag zou tenietdoen. Aldus verzet artikel $8 \mathrm{Hyp}$. W. zich ertegen dat de aannemer een vordering uit ongerechtvaardigde verrijking tegen de eigenaar instelt in geval van samenloop van schuldeisers op het vermogen van de huurder. Dit is echter precies de situatie waarin het instellen van dergelijke vordering voor de aannemer wellicht het meest nuttig zou zijn.

Besluit is dan ook dat er in de huidige stand van het recht geen goede redenen zijn om de werking van de subsidiariteitsvereiste nog langer te beperken tot de verhouding tussen verweerder en eiser. Bijgevolg zou een vordering uit ongerechtvaardigde verrijking moeten worden geweigerd zodra de eiser over een andere actiemogelijkheid beschikt, hetzij tegen de verweerder, hetzij tegen een derde.

\subsection{Afwezigheid van fout van de eiser?}

44. In de huidige stand van het recht is het onzeker of een fout van de eiser, zonder dewelke de ongerechtvaardigde verrijking van de verweerder niet had plaatsgevonden, een vordering uit ongerechtvaardigde verrijking geheel of gedeeltelijk uitsluit. ${ }^{73}$

Een van de schaarse rechterlijke beslissingen over deze problematiek betreft een arrest van het hof van beroep te Antwerpen van I4 december I988.764 Een reisbijstandsverzekeraar had een overleden vrouw uit het buitenland gerepatrieerd. Naderhand bleek dat die vrouw niet was aangesloten bij die reisbijstandsverzekeraar. Hierop stelde de reisbijstandsverzekeraar een vordering uit ongerechtvaardigde verrijking in tegen haar kinderen, die er te goeder trouw waren van uitgegaan dat hun moeder wel over een reisbijstandsverzekering beschikte. Het hof van beroep te Antwerpen oordeelde evenwel dat de verzekeraar onzorgvuldig had gehandeld (door niet behoorlijk te onderzoeken of de vrouw wel verzekerd was), zodat de verzekeraar

762 Cass. 20 februari i991, Arr. Cass. 1990-91, 671.

763 C. Marr, 'L'enrichissement sans cause. Un fondement d'équité sous une apparente rigeur...', in: S. Stijns en P. Wéry (eds.), De bronnen van niet-contractuele verbintenissen, Brugge, die Keure, 2007, 254-255, nr. 48 .

764 Antwerpen I4 december I988, Pas. I989, II, I44. 
gedeeltelijk aansprakelijk moest worden gesteld voor het door hem geleden nadeel (met andere woorden voor zijn verarming). Het aandeel van de verzekeraar in het door hem geleden nadeel werd vervolgens naar billijkheid begroot op de helft.

M.i. valt het echter moeilijk te rechtvaardigen dat een fout van de eiser (zonder dewelke de ongerechtvaardigde verrijking van de verweerder niet had plaatsgevonden) een vordering uit ongerechtvaardigde verrijking zou beperken of uitsluiten. ${ }^{76}$ Wat de verweerder in uitvoering van zijn restitutieplicht moet betalen, kan immers niet als schade worden gezien. In de hierboven besproken zaak zouden de kinderen van de overleden vrouw op grond van de principes die de vordering uit ongerechtvaardigde verrijking beheersen, maximaal gehouden kunnen worden de kosten te vergoeden die zij door de repatriëring van hun moeder door de rechtsbijstandsverzekeraar daadwerkelijk hadden bespaard..$^{66}$ Dit zijn kosten die zij hoe dan ook hadden moeten maken, zodat de vergoeding van deze kosten aan de reisbijstandsverzekeraar niet als schade kan worden gezien.

Een zelfde redenering wordt trouwens toegepast bij de vordering uit onverschuldigde betaling, die - net als de vordering uit ongerechtvaardigde verrijking - een toepassing vormt van het algemeen rechtsbeginsel dat niemand zich ten koste van een ander ongerechtvaardigd mag verrijken. ${ }^{767}$ Een vordering uit onverschuldigde betaling wordt immers ook niet uitgesloten wanneer de solvens een fout heeft begaan..$^{68}$

45. Het is echter niet uitgesloten dat de fout van de eiser (zonder dewelke de ongerechtvaardigde verrijking van de verweerder niet had plaatsgevonden) aan de verweerder schade berokkent, die hij niet had geleden indien de fout (en dus zijn ongerechtvaardigde verrijking) niet had plaatsgevonden. Voor deze schade kan de verweerder op grond van de regels inzake foutaansprakelijkheid schadevergoeding van de eiser bekomen. In voorkomend geval kan deze schadevergoeding gecompenseerd worden met de vergoeding die de verweerder aan de eiser verschuldigd is op grond van de principes inzake ongerechtvaardigde verrijking. ${ }^{769}$

765 Zie ook P. Maes, 'Ongegronde vermogensverschuivingen en driepartijenverhoudingen', TPR 20IO, (I87) 2II-2I2, nr. 24. Anders: B. De Coninck, 'A titre subsidiaire, l'enrichissement sans cause...', in: P. Wéry (ed.), La théorie générale des obligations. Suite, Luik, Editions Formation Permanente CUP, 2002, 65-66, nr. I4; P. Van Ommeslaghe, Droit des obligations, II, Sources des obligations (deuxième partie), Brussel, Bruylant, 2010, nr. 788.

766 Vgl. supra, nr. 9 en infra, nr. 58.

767 V. Sagaert, 'Wat als het vermogen gaat schuiven? Casuïstiek rond zaakwaarneming, onverschuldigde betaling en ongerechtvaardigde verrijking', in: S. Stijns (ed.), Verbintenissenrecht, in Themis, Brugge, die Keure, 2007, 7I, nr. I.

768 V. Sagaert, 'Wat als het vermogen gaat schuiven? Casuïstiek rond zaakwaarneming, onverschuldigde betaling en ongerechtvaardigde verrijking', in: S. Stijns (ed.), Verbintenissenrecht, in Themis, Brugge, die Keure, 2007, 84, nr. 2I; W. van Gerven, Verbintenissenrecht, Leuven, Acco, 2006, 284.

769 V. Sagaert, 'Wat als het vermogen gaat schuiven? Casuïstiek rond zaakwaarneming, onverschuldigde betaling en ongerechtvaardigde verrijking', in: S. Stijns (ed.), Verbintenissenrecht, in Themis, Brugge, die Keure, 2007, 9I, nr. 30. 
Een illustratie. Een bank had een mandaat gekregen om jaarlijkse fiscale voorafbetalingen voor een klant te doen. Nadat de klant dit mandaat had opgezegd, doet de bank toch nog een storting aan de fiscale administratie. De klant had echter de bedoeling om dat jaar geen voorafbetaling te doen. Het hof van beroep te Luik oordeelde dat de fiscale administratie de ontvangen storting op grond van de theorie van het schijnmandaat mocht behouden. Vervolgens besliste het hof dat de bank het gestorte bedrag op grond van ongerechtvaardigde verrijking van de klant kon terugvorderen. Door de storting aan de fiscale administratie was de klant immers verrijkt (omdat de door de bank gedane storting zou worden aangewend tot voldoening van een belastingschuld dan wel door de fiscus aan de klant zou worden terugbetaald) ten koste van de bank, zonder dat daarvoor een juridische rechtvaardiging voorhanden was. Dat de bank een fout had begaan, zonder dewelke de ongerechtvaardigde verrijking niet had plaatsgevonden, stond hieraan niet in de weg. Wel aanvaardde het hof van beroep dat de bank gehouden was de schade te vergoeden die de klant had geleden doordat de bank voor hem een voorafbetaling had gedaan, terwijl de klant dit zelf niet van plan was. Deze schade werd ex aequo et bono begroot op 500 euro. ${ }^{70}$

\section{Gevolgen}

46. Indien de voorwaarden voor de vordering uit ongerechtvaardigde verrijking vervuld zijn, rust op de verweerder de verplichting om de verrijking die hij ten koste van de eiser heeft verkregen, aan de eiser te restitueren.

Volgens sommige auteurs moet de verweerder deze verrijking bij voorkeur in natura aan de eiser teruggeven..$^{71}$ In de rechtspraak zijn echter geen toepassingen van deze regel terug te vinden.

Dit is geen toeval. Hoe dan ook is teruggave van een verrijking in natura per definitie slechts mogelijk indien de verkregen verrijking uit een goed bestond, en dan nog slechts op voorwaarde dat dit goed nog in natura in het vermogen van de verweerder aanwezig is. In dat geval zal in de regel reeds een andere vordering ter beschikking van de eiser staan, namelijk een vordering uit onverschuldigde betaling (tegen de verweerder of tegen een derde) dan wel een revindicatievordering (tegen de verweerder). Een vordering uit ongerechtvaardigde verrijking is dan, gelet op haar subsidiair karakter, niet mogelijk.

Bij een succesvolle vordering uit ongerechtvaardigde verrijking zal de verweerder de verrijking die hij ongerechtvaardigd ten koste van de eiser heeft verkregen, bijgevolg

770 Luik I maart 2002, JLMB 2003, 961, noot C. Winandy.

77 I H. De Page, Traité élémentaire de droit civil belge, III, Brussel, Bruylant, I967, nr. 46; P. Maes, 'Ongegronde vermogensverschuivingen en driepartijenverhoudingen', TPR 2010, (I87) 210, nr. 23; C. Marr, 'L'enrichissement sans cause. Un fondement d'équité sous une apparente rigeur...', in: S. Stijns en P. Wéry (eds.), De bronnen van niet-contractuele verbintenissen, Brugge, die Keure, 2007, 248 , nr. 4I. 
in de regel moeten restitueren door betaling van een geldelijke vergoeding aan de eiser. Zoals hierna zal blijken, vertoont de klassieke berekeningswijze voor deze vergoeding echter gebreken (paragraaf 4.I). Om hieraan te verhelpen, wordt een eerste aanzet gegeven voor een alternatieve voorstelling van de gevolgen van de vordering uit ongerechtvaardigde verrijking (paragraaf 4.2).

\section{I. Klassieke zienswijze}

47. Als de voorwaarden voor de vordering uit ongerechtvaardigde verrijking vervuld zijn, moet de verweerder volgens de klassieke zienswijze aan de eiser een vergoeding betalen, gelijk aan het bedrag van zijn verrijking, zonder dat deze vergoeding evenwel meer mag bedragen dan de verarming van de eiser. ${ }^{72}$

In het bestaande recht gaat voornamelijk aandacht naar de vraag op welk tijdstip de verrijking van de verweerder (paragraaf 4.I.I) en de verarming van de eiser (paragraaf 4.I.2) moeten worden beoordeeld.

\subsubsection{Tijdstip van beoordeling van de verrijking}

48. Volgens de dominante zienswijze moet de verrijking van de verweerder beoordeeld worden op de datum van het instellen van de vordering uit ongerechtvaardigde verrijking. ${ }^{773}$

Bijgevolg kan de verweerder maximaal gehouden worden tot vergoeding van het bedrag van wat nog van de verrijking in zijn vermogen overbleef op het ogenblik waarop de vordering uit ongerechtvaardigde verrijking werd ingesteld. Wanneer de verrijking geheel of gedeeltelijk uit het vermogen van de verweerder is verdwenen, komt dit dus niet ten laste van de verweerder, maar ten laste van de eiser (die ten belope van het 'verdwenen' gedeelte van de verrijking immers geen vergoeding zal ontvangen).

772 B. De Coninck, 'A titre subsidiaire, l'enrichissement sans cause...', in: P. Wéry (ed.), La théorie générale des obligations. Suite, Luik, Editions Formation Permanente CUP, 2002, 93, nr. 46; H. De Page, Traité élémentaire de droit civil belge, III, Brussel, Bruylant, I967, nr. 47; P. Maes, 'Ongegronde vermogensverschuivingen en driepartijenverhoudingen', TPR 2010, (I87) 210, nr. 23; C. Marr, 'L'enrichissement sans cause. Un fondement d'équité sous une apparente rigeur...', in: S. Stijns en P. Wéry (eds.), De bronnen van niet-contractuele verbintenissen, Brugge, die Keure, 2007, 248, nr. 4I; W. van Gerven, Verbintenissenrecht, Leuven, Acco, 2006, 29I; P. Van Ommeslaghe, Droit des obligations, II, Sources des obligations (deuxième partie), Brussel, Bruylant, 20Io, nr. 792.

773 R. Dekkers, Handboek burgerlijk recht, II, Brussel, Bruylant, I97I, nr. 3I4; A. Kluyskens, Beginselen van burgerlijk recht, I, De verbintenissen, Antwerpen, Standaard, I948, nr. 360; C. Marr, 'L'enrichissement sans cause. Un fondement d'équité sous une apparente rigeur...', in: S. Stijns en P. Wéry (eds.), De bronnen van niet-contractuele verbintenissen, Brugge, die Keure, 2007, 250, nr. 44 ; S. Stijns, D. van Gerven en P. Wéry, 'Chronique de jurisprudence. Les obligations: les sources (I985-I995)', JT 1996, (689) 700, nr. 32; P. Van Ommeslaghe, Droit des obligations, II, Sources des obligations (deuxième partie), Brussel, Bruylant, 2010, nr. 792. 
49. Bepaalde auteurs pleiten er echter voor de verrijking van de verweerder principieel op het ogenblik van de verkrijging ervan te beoordelen. ${ }^{774}$ Op deze regel maken zij echter een uitzondering voor het geval de verweerder op het ogenblik van het verlies van de verrijking te goeder trouw was. Meer bepaald dient de verweerder volgens deze rechtsleer niet in te staan voor het (geheel of gedeeltelijk) verlies van de verrijking, zolang hij niet wist en ook niet behoorde te weten dat zijn verrijking ongerechtvaardigd was. ${ }^{775}$

\section{Deze minderheidsopvatting kan grotendeels worden bijgetreden.}

Zoals in principe voor elke persoonlijke rechtsvordering geldt, moet het voorwerp van de vordering uit ongerechtvaardigde verrijking worden vastgesteld op het ogenblik van haar ontstaan. Dit is het ogenblik waarop al haar toepassingsvoorwaarden in vervulling zijn gegaan. ${ }^{776}$ In de regel is dit het ogenblik waarop de verweerder de ongerechtvaardigde verrijking verkreeg. ${ }^{777}$

$\mathrm{Nu}$ het voorwerp van de vordering uit ongerechtvaardigde verrijking volgens de klassieke zienswijze gelijk is aan het bedrag van de verrijking van de verweerder (zonder evenwel het bedrag van de verarming van de eiser te mogen overtreffen), ${ }^{778}$ moet het bedrag van de verrijking van de verweerder bijgevolg worden vastgesteld op het ogenblik van het ontstaan van de vordering uit ongerechtvaardigde verrijking.

Indien deze regel onverkort wordt toegepast, zou de verweerder steeds moeten instaan voor het geheel of gedeeltelijk verlies van de door hem verkregen verrijking. Dit valt echter moeilijk te verantwoorden zolang hij te goeder trouw was, dat wil zeggen zolang hij niet wist en ook niet behoorde te weten dat hij de verrijking zou moeten restitueren (en dat hij dus zou moeten instaan voor het verlies ervan). In dat geval vereist de bescherming van het rechtmatig vertrouwen van de verweerder dan ook dat hij niet gehouden kan worden in te staan voor het geheel of gedeeltelijk verlies van de verkregen verrijking.

774 H. De Page, Traité élémentaire de droit civil belge, III, Brussel, Bruylant, I967, nr. 49; V. Sagaert, 'Ongerechtvaardigde verrijking en gewijzigde omstandigheden', TPR 200I, (583) 593, nr. 9; V. Sagaert, 'Wat als het vermogen gaat schuiven? Casuïstiek rond zaakwaarneming, onverschuldigde betaling en ongerechtvaardigde verrijking', in: S. Stijns (ed.), Verbintenissenrecht, in Themis, Brugge, die Keure, 2007, 93, nr. 34.

775 V. Sagaert, 'Ongerechtvaardigde verrijking en gewijzigde omstandigheden', TPR 200I, (583) 624 , nr. 35; V. Sagaert, 'Wat als het vermogen gaat schuiven? Casuïstiek rond zaakwaarneming, onverschuldigde betaling en ongerechtvaardigde verrijking', in: S. Stijns (ed.), Verbintenissenrecht, in Themis, Brugge, die Keure, 2007, 93, nr. 34.

776 Vgl. voor Nederland: C. Asser, A. S. Hartkamp en C. H. Sieburgh, Verbintenissenrecht. De verbintenis uit de wet, in: Mr. C. Asser's handleiding tot de beoefening van het Nederlands burgerlijk recht, 6-IV, Deventer, Kluwer, 20II, nr. 482; J. Spier, T. Hartlief, G. E. Van Maanen en R. D. Vriesendorp, Verbintenissen uit de wet en schadevergoeding, in: Studiereeks burgerlijk recht, Deventer, Kluwer, 2009, nr. 320. Zie ook het Nederlandse preadvies van Ton Hartlief.

777 Vgl. C. von Bar en E. Clive (eds.), Principles, Definitions and Model Rules of European Private Law. Draft Common Frame of Reference. Full edition, IV, München, Sellier, 2009, 4I28.

778 Supra, nr. 47 . 
Aldus is de verweerder die niet wist en ook niet behoorde te weten dat hij de verrijking aan de eiser zou moeten teruggeven, slechts gehouden tot teruggave van wat van de verrijking nog in zijn vermogen overbleef op het ogenblik waarop hij niet langer kon volhouden te goeder trouw te zijn, i.e. het ogenblik vanaf wanneer hij rekening diende te houden met de mogelijkheid dat hij de verkregen verrijking zou moeten restitueren. Dit is ten laatste het ogenblik van het instellen van de vordering uit ongerechtvaardigde verrijking. Dit kan echter ook vroeger zijn, bijvoorbeeld op het ogenblik van de ingebrekestelling van de verweerder.

Deze oplossing ligt in de lijn van het Nederlandse recht. Op grond van artikel 6:2I2 (3) NBW moet de verrijkte immers niet instaan voor een vermindering van de verkregen verrijking, indien deze vermindering plaatsvond 'in een periode waarin de verrijkte redelijkerwijze met een verplichting tot vergoeding van de schade geen rekening behoefde te houden. ${ }^{779}$

\subsubsection{Tijdstip van beoordeling van de verarming}

5I. Volgens de klassieke opvatting mag het bedrag van de door de verweerder verschuldigde vergoeding niet hoger zijn dan het bedrag van de verarming van de eiser. $^{780}$

Over het tijdstip waarop de verarming moet worden beoordeeld, doen slechts weinige auteurs uitspraak. Bovendien verdedigen zij veelal uiteenlopende opvattingen. Volgens sommigen moet de beoordeling van de verarming plaatsvinden op het ogenblik van het ontstaan van de vordering uit ongerechtvaardigde verrijking. ${ }^{78 \mathrm{r}}$ Anderen zijn daarentegen van oordeel dat de verarming moet worden beoordeeld op het ogenblik van het instellen van de vordering uit ongerechtvaardigde verrijking, ${ }^{782}$

779 Zie hierover: J. Spier, T. Hartlief, G. E. Van Maanen en R. D. Vriesendorp, Verbintenissen uit de wet en schadevergoeding, in: Studiereeks burgerlijk recht, Deventer, Kluwer, 2009, nr. 32I: 'De ratio hierachter is dat de verrijkte in die periode met de goederen waaruit zijn verrijking bestaat is omgegaan op een manier dat het risico van waardevermindering geheel voor zijn rekening komt. Soms is men wat onzorgvuldiger met eigen spullen dan wanneer men weet dat men (de waarde van) die spullen voor een ander moet beheren. Het wordt dan niet billijk geacht dat een waardevermindering als gevolg hiervan aan de verrijkte wordt toegerekend in het kader van de berekening van de schadevergoeding die aan de verarmde moet worden betaald. Uiteraard geldt dit alleen voor zolang de verrijkte geen rekening hoefde te houden met een schadevergoedingsverplichting. Zodra hij dit wel moet doen, komen verminderingen van de verrijking die hem kunnen worden toegerekend wel voor zijn risico.'

780 B. De Coninck, 'A titre subsidiaire, l'enrichissement sans cause...' in: P. Wéry (ed.), La théorie générale des obligations. Suite, Luik, Editions Formation Permanente CUP, 2002, 93, nr. 46; H. De Page, Traité élémentaire de droit civil belge, III, Brussel, Bruylant, I967, nr. 47; W. van Gerven, Verbintenissenrecht, Leuven, Acco, 2006, 29I; P. Van Ommeslaghe, Droit des obligations, II, Sources des obligations (deuxième partie), Brussel, Bruylant, 2010, nr. 792.

78I C. Marr, 'L'enrichissement sans cause. Un fondement d'équité sous une apparente rigeur...', in: S. Stijns en P. Wéry (eds.), De bronnen van niet-contractuele verbintenissen, Brugge, die Keure, 2007, 250, nr. 44 .

782 S. Stijns, D. van Gerven en P. Wéry, 'Chronique de jurisprudence. Les obligations: les sources (I985-I995)', JT i996, (689) 700, nr. 32. 
of zelfs op het ogenblik van de rechterlijke uitspraak, omdat de verbintenis van de verweerder een waardeschuld zou zijn..$^{783}$

52. De gedachte dat de verbintenis van de verweerder een waardeschuld zou zijn, moet echter worden verworpen.

Zoals hoger gezien, zal een vordering uit ongerechtvaardigde verrijking naar Belgisch recht in principe van meet af aan de betaling van een geldsom tot voorwerp hebben..$^{74} \mathrm{Nu}$ is een schuld die van bij de aanvang tot betaling van een geldsom strekt naar Belgisch recht geen waardeschuld, maar een geldschuld, ${ }^{785}$ ook al moet de rechter het precieze bedrag van de verschuldigde geldsom later nog vaststellen. ${ }^{78}$ Bijgevolg moet de verbintenis van de verweerder bij de vordering uit ongerechtvaardigde verrijking niet als een waardeschuld, maar als een geldschuld worden gekwalificeerd.

Het zou trouwens moeilijk te verantwoorden vallen de principes inzakewaardeschulden op de verbintenis van de verweerder toe te passen. Kenmerkend voor een waardeschuld is dat de door de schuldenaar te vergoeden 'waarde' moet worden begroot op het ogenblik van de vaststelling van de vergoeding voor de rechter. Hierbij zal het nominale bedrag van de waardeschuld doorgaans hoger zijn op het ogenblik van de begroting door de rechter, dan bij het ontstaan van de waardeschuld. Volgens het Hof van Cassatie mag deze verhoging niet als een verrijking van de schuldeiser van de waardeschuld worden gezien, maar is zij het gevolg van de vertraging waarmee de schuldenaar zijn schuld nakomt. ${ }^{787}$ Voor de klassieke waardeschulden, met name de verbintenis tot betaling van een schadevergoeding wegens contractuele wanprestatie of onrechtmatige daad, valt deze redenering te verdedigen. Het ontstaan van dergelijke waardeschulden is immers steeds het gevolg van een aan de schuldenaar toerekenbare fout, zodat het inderdaad verantwoord is dat de schuldenaar voor de vertraging in de betaling moet opdraaien. Bij een verbintenis uit ongerechtvaardigde verrijking is dit daarentegen niet het geval: het ontstaan van deze verbintenis is immers niet te wijten aan een fout van de schuldenaar (de verweerder). Het valt

783 V. Sagaert, 'Wat als het vermogen gaat schuiven? Casuïstiek rond zaakwaarneming, onverschuldigde betaling en ongerechtvaardigde verrijking, in: S. Stijns (ed.), Verbintenissenrecht, in Themis, Brugge, die Keure, 2007, 93, nr. 34; P. Van Ommeslaghe, Droit des obligations, II, Sources des obligations (deuxième partie), Brussel, Bruylant, 2010, nr. 792.

784 Supra, nr. 46.

785 B. De Temmerman, 'Interest bij schadevergoeding uit wanprestatie en onrechtmatige daad. Een stand van zaken, tevens aanleiding tot een kritische beschouwing over de grondslagen van het Belgische schadevergoedingsrecht', TPR I999, (I277) I300, nr. I7.

786 C. Biquet-Mathieu en C. Delforge, 'Le régime juridique des intérêts - essai de synthese', in: P. Lecocq en C. Engels (eds.), Rechtskroniek voor de vrede- en politierechters 2008, Brugge, die Keure, 2008, 262, nr. 33; B. De Temmerman, 'Interest bij schadevergoeding uit wanprestatie en onrechtmatige daad. Een stand van zaken, tevens aanleiding tot een kritische beschouwing over de grondslagen van het Belgische schadevergoedingsrecht', TPR I999, (I277) I300-I30I, nr. I7; P. Wéry, Droit des obligations. Volume 1. Théorie générale du contrat, Brussel, Larcier, 2010, nr. 6og.

787 Cass. 8 mei I952, Arr. Verbr. I952, 499, Pas. I952, I, 570, concl. R. Hayoit de Thermicourt. 
dan ook niet in te zien waarom de verweerder van meet af aan zou moeten opdraaien voor de vertraging in de uitvoering van zijn restitutieplicht.

Besluit moet dan ook zijn dat de door de verweerder verschuldigde vergoeding in beginsel niet hoger mag zijn dan het bedrag van de verarming van de eiser, zoals begroot op het ogenblik waarop de verarming daadwerkelijk plaatsvond. Dit betekent echter niet dat de verweerder nooit meer dan dit bedrag aan de eiser verschuldigd kan zijn. Als geldschuld valt de verbintenis van de verweerder immers onder de toepassing van artikel II53 BW, ${ }^{788}$ zodat de verweerder op het verschuldigde bedrag (i.e. het bedrag van de verrijking, zonder dat dit evenwel het bedrag van de verarming mag te boven gaan) interesten verschuldigd is vanaf het ogenblik waarop hij in gebreke is. Dit laatste strookt overigens met wat een meerderheid van auteurs schrijft, zonder hierbij evenwel enige uitleg te geven. ${ }^{789}$

\subsection{Alternatieve benadering}

53. Hierboven is gebleken dat de traditionele voorstelling van de gevolgen van de vordering uit ongerechtvaardigde verrijking op verschillende punten gebrekkig is. Hierna volgt dan ook een voorstel om deze gevolgen voortaan anders te ordenen.

54. Net zoals in het bestaande recht, moet als uitgangspunt gelden dat een vordering uit ongerechtvaardigde verrijking een toepassing vormt van het algemeen rechtsbeginsel dat niemand zich ten koste van een ander ongerechtvaardigd mag verrijken..$^{70}$ Aldus moet de vordering uit ongerechtvaardigde verrijking er in eerste instantie toe strekken de ongerechtvaardigde verrijking van de verweerder ten koste van de eiser ongedaan te maken. Hiertoe dient de verweerder de verrijking die hij ten koste van de eiser heeft verkregen, aan deze laatste restitueren. ${ }^{79}$ Zoals gezien, zal deze restitutie naar Belgisch recht in de regel niet in natura plaatsvinden (omdat in die gevallen waarin restitutie in natura nog mogelijk is, de eiser in de regel over een andere rechtsvordering zal beschikken), maar wel door betaling van een geldelijke vergoeding..$^{92}$

788 De tekst van artikel II53 BW luidt:

'Inzake verbintenissen die alleen betrekking hebben op het betalen van een bepaalde geldsom, bestaat de schadevergoeding wegens vertraging in de uitvoering nooit in iets anders dan in de wettelijke interest, behoudens de bij wet gestelde uitzonderingen.

Die schadevergoeding is verschuldigd zonder dat de schuldeiser enig verlies hoeft te bewijzen. Zij is verschuldigd te rekenen van de dag der aanmaning tot betaling, behalve ingeval de wet ze van rechtswege doet lopen.

(...)'

789 Bergen 4 februari I99I, Rev. Not. B. I99I, 474; B. De Coninck, 'A titre subsidiaire, l'enrichissement sans cause...' in: P. Wéry (ed.), La théorie générale des obligations. Suite, Luik, Editions Formation Permanente CUP, 2002, 93, nr. 46; H. De Page, Traité élémentaire de droit civil belge, III, Brussel, Bruylant, I967, nr. 48; R. Kruithof, H. Bocken, F. De Ly en B. De Temmerman, 'Verbintenissen. Overzicht van rechtspraak (I98I-I992)', TPR I994, (I7I) 625, nr. 329; P. Van Ommeslaghe, Droit des obligations, II, Sources des obligations (deuxième partie), Brussel, Bruylant, 20Io, nr. 792.

790 Supra, nr. 5.

79I Vgl. supra, nr. 46.

792 Supra, nr. 46. 
Zoals hierboven toegelicht, moet het voorwerp van de vordering uit ongerechtvaardigde verrijking worden vastgesteld op het ogenblik van haar ontstaan (in de regel het ogenblik waarop de verweerder de verrijking verkreeg). ${ }^{793}$ Bijgevolg moet op dat ogenblik worden nagegaan ten belope van welk bedrag de verweerder ongerechtvaardigd werd verrijkt ten koste van de eiser. Het is dan in principe ten belope van dat bedrag dat de verweerder aan de eiser een vergoeding verschuldigd is.

55. Zoals hoger verdedigd, kan de vereiste dat de verrijking van de verweerder 'ten koste van' de eiser moet zijn gegaan, op twee manieren worden ingevuld.

Vooreerst is de verweerder ten koste van de eiser verrijkt, indien zijn verrijking het gevolg was van een verarming van de eiser.

In deze hypothese geldt als regel dat de verweerder aan de eiser een vergoeding moet betalen, gelijk aan het bedrag van zijn verrijking, zoals begroot op het ogenblik van het ontstaan van de vordering uit ongerechtvaardigde verrijking (in beginsel het ogenblik waarop de verweerder verrijking verkreeg), doch enkel in de mate waarin die verrijking het gevolg was van een verarming van de eiser. Aldus mag de door de verweerder verschuldigde vergoeding niet groter zijn dan het bedrag van de verarming van de eiser, te begroten op het ogenblik waarom de verarming daadwerkelijk plaatsvond..$^{794}$

Vaak zullen het tijdstip voor de beoordeling van de verrijking en dat van de verarming samenvallen. Dit is echter niet altijd het geval. Zo komen werken die een huurder aan het gehuurde goed heeft laten uitvoeren, niet onmiddellijk, maar pas bij de beëindiging van de huurrelatie aan de eigenaar bij wege van natrekking ten goede. ${ }^{795}$ Bijgevolg vindt de verrijking van de eigenaar pas op het einde van de huurrelatie plaats, terwijl de verarming van de huurder reeds eerder gebeurde, met name op het ogenblik dat hij voor de werken betaalde.

56. Daarnaast kan van een verrijking van de verweerder ten koste van de eiser ook sprake zijn indien de verweerder door een inbreuk op een recht van de eiser voordelen heeft verkregen..$^{796}$

In deze hypothese moet op het ogenblik van het ontstaan van de vordering uit ongerechtvaardigde verrijking worden beoordeeld in welke mate de verweerder door de inbreuk op het recht van de eiser ongerechtvaardigd werd verrijkt.

Indien de verweerder een inbreuk pleegde op een recht waarvan het economisch gebruik aan de eiser was voorbehouden (zoals het recht van afbeelding van de eiser

793 Supra, nr. 50.

794 Supra, nr. 52.

795 Supra, nr. 29 en voetnoot 7or.

796 Supra, nr. I9. 
of het auteursrecht van de eiser), rijst de vraag of de verweerder alle voordelen moet afgeven die hij ingevolge de inbreuk heeft verkregen, dan wel slechts die voordelen die aan de eiser waren toegekomen, indien de eiser met het gebruik van zijn recht door de verweerder had toegestemd. Moet, in het voorbeeld waarin een filmmaker een inbreuk heeft gemaakt op het auteursrecht van de auteur van een boek, de filmmaker alle winst afgeven die de film heeft opgebracht, of enkel dat deel dat aan de auteur zou zijn toegekomen indien de auteur zijn toestemming voor de film had gegeven?

Het lijkt alvast niet aangewezen de verbintenis van de verweerder te beperken tot de voordelen die normaal gezien aan de eiser waren toegekomen. Dit zou immers betekenen dat de eiser slechts aanspraak zou kunnen maken op wat hij onder de gegeven (markt)omstandigheden had kunnen vragen als vergoeding, indien hij aan de verweerder zijn toestemming had gegeven voor het gebruik van zijn recht ${ }^{797}$ (terwijl hij misschien niet eens zijn toestemming had willen geven). Aldus zou de verweerder weinig te verliezen hebben: hij loopt dan immers maximaal het risico een bedrag te betalen, gelijk aan de vergoeding die hij aan de eiser had moeten betalen indien deze laatste zijn toestemming had gegeven voor het gebruik van zijn recht.

Indien een vordering uit ongerechtvaardigde verrijking wegens inbreuk op een recht van de eiser echter precies werd toegelaten omdat de wet zelf onvoldoende prikkels bevat om potentiële inbreukplegers van een onrechtmatige inbreuk op dat recht te weerhouden, ${ }^{79^{8}}$ moet zij er noodzakelijkerwijze toe leiden dat de prikkel tot het begaan van de inbreuk effectief wordt weggenomen. Dit impliceert dat de verweerder niets mag overhouden aan de onrechtmatige inbreuk, zodat hij in principe de volledige (netto)verrijking die hij door de onrechtmatige inbreuk op het recht van de eiser heeft verkregen, aan de eiser zal moeten afgeven. ${ }^{799}$

57. Zoals hoger bepleit, moet de restitutieplicht van de verweerder beperkt worden indien hij niet wist (en ook niet behoorde te weten) dat hij de verkregen verrijking zou moeten teruggeven. In dat geval verdient het rechtmatig vertrouwen van de verweerder immers bescherming, zodat hij maximaal gehouden kan worden tot teruggave van wat van de verrijking nog in zijn vermogen overbleef op het ogenblik vanaf wanneer hij rekening diende te houden met de mogelijkheid dat hij de verkregen verrijking zou moeten restitueren. Zoals gezien, is dit ten laatste op het ogenblik van het instellen van de vordering uit ongerechtvaardigde verrijking, maar dit kan ook vroeger zijn, bijvoorbeeld op het ogenblik van de ingebrekestelling van de verweerder. ${ }^{800}$

797 Vgl. M. Kruithof, 'De vordering tot voordeeloverdracht', TPR 20II, (I3) 56, nr. 38.

798 Supra, nr. I9.

799 Vgl. M. Kruithof, 'De vordering tot voordeeloverdracht', TPR 20II, (I3) 56, nr. 38.

800 Supra, nr. 50. 
58. Naast het rechtmatig vertrouwen, verdient ook de wilsautonomie van de verweerder bescherming. Zoals hoger bepleit, mag de vordering uit ongerechtvaardigde verrijking er immers niet toe leiden dat de verweerder voor een opgedrongen prestatie zou moeten betalen.

Zoals eveneens gezien, kan dit resultaat technisch gezien op twee verschillende manieren worden bereikt: ofwel door het verrijkingsbegrip voor opgedrongen prestaties te beperken tot de door de verweerder bespaarde kosten (zoals in het bestaande recht reeds voor dienstprestaties gebeurt), ${ }^{80 \mathrm{r}}$ ofwel door de restitutieplicht van de verweerder voor opgedrongen prestaties te beperken tot de bespaarde kosten (zoals het DCFR doet). ${ }^{802}$

De laatste benadering, waarin niet het verrijkingsbegrip, maar wel de restitutieplicht van de verweerder bij opgedrongen prestaties wordt beperkt, lijkt praktisch gezien beter te combineren met de andere regels inzake de restitutieplicht van de verweerder.

Te denken valt aan de situatie waarin de eiser zonder toestemming van de verweerder nieuwe ramen in het onroerend goed van de verweerder heeft geplaatst. In dat geval komen de ramen in principe bij wege van natrekking aan de verweerder (als eigenaar van het onroerend goed) toe. Wanneer het niet de bedoeling van partijen was dat de verrijking die de verweerder aldus verkreeg, onvergoed zou blijven en de eiser over geen enkele andere rechtsvordering beschikt, kan de eiser in principe een vordering uit ongerechtvaardigde verrijking tegen de verweerder instellen.

Stel nu dat de verweerder pas na verloop van tijd kennis heeft van de nieuwe ramen. Zoals hoger verdedigd, is de verweerder in dat geval slechts gehouden tot restitutie van de verrijking die nog in zijn vermogen overbleef op het ogenblik vanaf wanneer hij rekening diende te houden met de mogelijkheid tot restitutie.

Indien er in dit geval voor gekozen wordt de verrijking van de verweerder te beperken tot zijn kostenbesparing, dan moet op het ogenblik waarop de verweerder met een verplichting tot restitutie rekening moest houden, begroot worden welke kostenbesparing de plaatsing van de ramen heeft opgeleverd. Dit zal geen gemakkelijke opgave zijn, aangezien de ramen ondertussen waarschijnlijk al verouderd (of misschien zelfs beschadigd zijn) en daardoor in waarde zullen verminderd zijn.

Indien daarentegen wordt geopteerd voor een beperking van de restitutieplicht van de verweerder tot de bespaarde kosten, kent de restitutieplicht van de verweerder in de voorliggende casus een dubbele beperking. Vooreerst is zijn restitutieplicht beperkt tot de meerwaarde die zijn onroerend goed door de ramen heeft verkregen, te beoordelen op het ogenblik waarop de verweerder redelijkerwijze met een

8or Supra, nrs. 9-II.

802 Supra, nr. I2. 
verplichting tot restitutie rekening diende te houden. Verder kan de door hem verschuldigde vergoeding ook nooit meer bedragen dan de kosten die hij heeft bespaard, te begroten op het ogenblik van het ontstaan van de vordering uit ongerechtvaardigde verrijking. Deze benadering lijkt mij praktisch gezien beter hanteerbaar en moet daarom de voorkeur genieten.

59. Verder werd reeds toegelicht dat de verbintenis van de verweerder geen waardeschuld, maar een geldschuld is die onderworpen is aan artikel $I_{53} \mathrm{BW} .{ }^{803}$ Bijgevolg moet de verweerder op de door hem verschuldigde vergoeding interesten betalen vanaf het ogenblik waarop hij in gebreke is.

6o. Concluderend kunnen de volgende principes worden geformuleerd:

I) Als hoofdregel geldt dat, indien de vereisten voor de vordering uit ongerechtvaardigde verrijking vervuld zijn, de verweerder aan de eiser een vergoeding moet betalen, gelijk aan het bedrag van de verrijking (i.e. het in geld waardeerbaar voordeel) die hij ten koste van de eiser heeft verkregen. Dit bedrag is te begroten op het tijdstip van het ontstaan van de vordering uit ongerechtvaardigde verrijking.

2) Op deze hoofdregel gelden drie uitzonderingen (die cumulatief kunnen worden toegepast):

a) Indien de verrijking van de verweerder het gevolg was van een verarming van de eiser, mag de door de verweerder verschuldigde vergoeding niet groter zijn dan het bedrag van de verarming van de eiser. Dit bedrag moet worden begroot op het ogenblik waarop de verarming daadwerkelijk plaatsvond.

b) Indien de verweerder niet wist en ook niet behoorde te weten dat hij de verkregen verrijking moest teruggeven, is hij slechts tot restitutie gehouden van wat van de verrijking nog in zijn vermogen overbleef op het ogenblik vanaf wanneer hij redelijkerwijze rekening moest houden met de mogelijkheid tot restitutie.

c) Indien de door de verweerder verkregen verrijking niet vatbaar was voor teruggave in natura, kan de verweerder maximaal gehouden worden tot vergoeding van de kosten die hij door de verkregen verrijking heeft uitgespaard, te begroten op het ogenblik van het ontstaan van de vordering uit ongerechtvaardigde verrijking. Deze uitzondering geldt echter enkel indien de verrijking zonder toestemming van de verweerder plaatsvond.

3) Op de door hem verschuldigde vergoeding is de verweerder op grond van artikel II53 BW interesten verschuldigd vanaf het ogenblik waarop hij in gebreke is.

803 Supra, nr. 52. 


\section{Ongerechtvaardigde verrijking als verweermiddel?}

6r. Tot nog toe werd in het interne Belgische recht nauwelijks aandacht besteed aan de vraag of het algemeen rechtsbeginsel dat niemand zich ten koste van een ander ongerechtvaardigd mag verrijken, ook als verweermiddel kan worden ingeroepen, met andere woorden om een andere vordering (geheel of gedeeltelijk) te doen afwijzen, omdat de toewijzing ervan tot een ongerechtvaardigde verrijking van de eiser ten koste van de verweerder zou leiden. ${ }^{804}$

62. Het Europese Hof van Justitie lijkt deze gedachte alvast niet ongenegen te zijn.

Zo heeft het Hof al herhaaldelijk bevestigd dat lidstaten de terugbetaling van in strijd met het EU-recht geheven betaalde belastingen kunnen weigeren indien dit zou leiden tot een ongerechtvaardigde verrijking van degene die om de terugbetaling verzoekt.

Te denken valt aan de situatie waarin een bedrijf belastingen heeft betaald die naderhand in strijd met het EU-recht bleken. In dat geval is de nationale overheid in principe gehouden de door het bedrijf ten onrechte betaalde belastingen terug te betalen. Wanneer het bedrijf de belastingen echter aan zijn klanten heeft doorberekend en deze doorberekening hem geen nadeel (bv. verlies van omzet, winst of marktaandeel) heeft toegebracht, zou het bedrijf ongerechtvaardigd worden verrijkt indien het terugbetaling van die belastingen door de overheid zou kunnen bekomen. In die omstandigheden verzet het EU-recht zich er volgens het Hof van Justitie niet tegen dat het nationale recht - dat bij gebrek aan Europese regeling immers op de vordering tot terugbetaling van toepassing is - de terugbetaling van de belastingen uitsluit. ${ }^{805}$ Dit wordt ook wel de toepassing van het doorberekeningsverweer of het verweer van passing on genoemd.

63. Ook in de sfeer van het mededingingsrecht zijn toepassingen van een 'exceptie van ongerechtvaardigde verrijking' denkbaar.

Stel dat een exclusieve afnameovereenkomst tussen een brouwerij en een caféuitbater wordt vernietigd wegens strijdigheid met het mededingingsrecht, bijvoorbeeld omdat de brouwerij aan die café-uitbater hogere bierprijzen aanrekende dan aan zelfstandige caféhouders. ${ }^{806}$ Deze vernietiging brengt mee dat zowel de brouwerij als de café-uitbater de prestaties die zij in uitvoering van de exclusieve afna-

804 Zie evenwel W. van Gerven, Verbintenissenrecht, Leuven, Acco, 2006, 473-478.

805 HvJ 27 februari I980, nr. 68/79, Just; HvJ 9 november I983, nr. I99/82, San Giorgio; HvJ I4 januari I997, nr. C-I92/95 t.e.m. C-2I8/95, Comateb e.a.; HvJ 6 september 20II, nr. C-398/o9, Lady \& Kid. Vgl. ook A. S. Hartkamp, 'Ongerechtvaardigde verrijking en onverschuldigde betaling in het Europese Gemeenschapsrecht', in: A. S. Hartkamp, C. H. Sieburgh en L. A. D. Keus (eds.), De invloed van het Europese recht op het Nederlandse privaatrecht, in Onderneming en Recht, Deel 42-I, Deventer, Kluwer, 2007, 555, nr. I4.

806 Dit waren de feiten die aanleiding gaven tot het belangwekkende Courage arrest van het Hof van Justitie (HvJ 20 september 200I, nr. C-453/99). 
meovereenkomst ontvingen, moeten teruggeven. Aldus moet de brouwerij de prijs die de caféhouder haar voor het afgenomen bier had betaald, aan de café-uitbater terugbetalen. Het is echter niet ondenkbaar dat de café-uitbater de te hoge bierprijs aan zijn klanten heeft doorberekend. Kan de brouwerij in dat geval haar restitutieplicht verminderen door in te roepen dat de café-uitbater ongerechtvaardigd zou worden verrijkt indien zij gehouden wou worden ook dat gedeelte van de bierprijs terug te betalen dat de café-uitbater op zijn klanten heeft afgewenteld? ${ }^{807}$

64. Of in de huidige stand van het Belgisch recht plaats is voor een exceptie van ongerechtvaardigde verrijking, lijkt op het eerste gezicht eerder twijfelachtig. Bij gebrek aan uitdrukkelijke wettelijk basis, zou deze exceptie in de huidige stand van het recht immers 'enkel' kunnen worden gesteund op het algemeen rechtsbeginsel dat niemand zich ten koste van een ander ongerechtvaardigd mag verrijken. Zoals reeds gezien, mag een beroep op dit algemeen rechtsbeginsel niet ingaan tegen de wet. Aldus valt moeilijk te verantwoorden dat dit algemeen rechtsbeginsel bijvoorbeeld de wettelijke regels inzake onverschuldigde betaling zou kunnen doorkruisen.

Dit hoeft echter niet te betekenen dat een rechter een vordering uit onverschuldigde betaling (of een vordering met een andere wettelijke grondslag) steeds integraal moet inwilligen. In bepaalde gevallen kan het integraal opeisen van de vergoeding waarop de eiser krachtens de wet aanspraak kan maken, immers kennelijk onredelijk zijn. Alsdan kan de rechter de door de eiser gevorderde vergoeding matigen op grond van een ander algemeen rechtsbeginsel, dat - net zoals het verrijkingsverbod - op een billijkheidsprincipe steunt. Het betreft het algemeen rechtsbeginsel van het verbod van rechtsmisbruik dat, anders dan het verrijkingsverbod, wel steeds aan een wettelijke bepaling kan worden gekoppeld, met name artikel II34, lid 3 BW (in een contractuele context) of artikel $1382 \mathrm{BW}$ (in een niet-contractuele context). Voor het algemeen rechtsbeginsel van het verbod van rechtsmisbruik geldt bijgevolg niet dat het in geen geval kan ingaan tegen een wettelijke bepaling.

65. Ten slotte kan nog worden opgemerkt dat bij vorderingen uit onrechtmatige daad, het schadevereiste een ongerechtvaardigde verrijking van de eiser in de weg staat. $^{808}$

Stel dat enkele grote brouwerijen prijsafspraken hebben gemaakt om de bierprijzen kunstmatig hoog te houden. Na enige tijd lopen zij een veroordeling op van de Europese Commissie wegens overtreding van het kartelverbod (cf. artikel Ior van het Verdrag betreffende de werking van de Europese Unie). Vervolgens stelt een caféuitbater, die bij een van deze brouwerijen bier had afgenomen, een vordering uit onrechtmatige daad in om compensatie te bekomen voor de te hoge bierprijs die

807 Vgl. J. Baeck, Restitutie na vernietiging of ontbinding van overeenkomsten, Antwerpen, Intersentia, 20I2, nr. 224.

808 Vgl. T. Schoors, T. Baeyens en W. Devroe, 'Schadevergoedingsacties na kartelinbreuken', NjW 20II, (I98) 204-205, nr. 24. 
hij heeft betaald. Stel dat ook in dit voorbeeld de café-uitbater de aan de brouwerij betaalde (te hoge) bierprijs aan zijn klanten heeft doorberekend. Indien deze doorberekening de café-uitbater geen nadeel heeft toegebracht (bv. verlies van omzet of van klanten), beschikt de café-uitbater bij gebrek aan schade niet over een vordering uit onrechtmatige daad tegen de brouwerij bij wie hij het bier had afgenomen. Een beroep op een exceptie van ongerechtvaardigde verrijking om de vordering van de café-uitbater te doen stranden, is hier bijgevolg overbodig.

\section{Besluit}

66. Naar Belgisch recht is de vordering uit ongerechtvaardigde verrijking bedoeld om leemtes in de wet op te vullen. In de praktijk wordt echter niet zo vaak een beroep gedaan op deze rechtsfiguur. Dit komt omdat zij naar Belgisch recht onderontwikkeld is. Onbekend maakt inderdaad vaak onbemind.

Om hieraan tegemoet te komen, werd in dit preadvies een eerste aanzet gegeven tot verfijning van zowel de toepassingsvoorwaarden als de gevolgen van de vordering uit ongerechtvaardigde verrijking. Hierbij werd duidelijk dat de vordering uit ongerechtvaardigde verrijking naar Belgisch recht meer potentieel heeft dan meestal wordt gedacht. Er zijn verschillende domeinen van het privaatrecht waar deze vordering een toekomst heeft omdat het wettenrecht er momenteel tekort schiet. Zo is gebleken dat deze vordering nuttig kan worden ingezet in de sfeer van het familiaal vermogensrecht, het zakenrecht en het zekerheidsrecht, net zoals bij inbreuken op intellectuele-eigendomsrechten of persoonlijkheidsrechten.

Dat de vordering uit ongerechtvaardigde verrijking naar Belgisch recht 'slechts' kan worden aangewend om leemtes in de wet op te vullen, brengt noodzakelijkerwijze mee dat deze vordering een subsidiair karakter heeft. In de huidige stand van het recht wordt inderdaad unaniem aanvaard dat geen vordering uit ongerechtvaardigde verrijking beschikbaar is indien de eiser over een andere actiemogelijkheid tegen de verweerder beschikt. In dit preadvies werd er echter voor gepleit om een vordering uit ongerechtvaardigde verrijking eveneens uit te sluiten indien de eiser over een actiemogelijkheid tegen een derde beschikt. In dat geval is er immers geen lacune in de wet, zodat er geen reden is om een vordering uit ongerechtvaardigde verrijking toe te laten. In geval van insolvabiliteit van deze derde (i.e. precies de situatie waarin het instellen van een vordering uit ongerechtvaardigde verrijking tegen de verweerder in de praktijk het meeste nut vertoont), dreigt het toelaten van de vordering uit ongerechtvaardigde verrijking bovendien op onverantwoorde wijze afbreuk te doen aan het gelijkheidsbeginsel tussen schuldeisers.

Op dit ogenblik lijkt er in België geen nood te bestaan om te tornen aan de louter aanvullende werking en, daarmee samenhangend, aan het subsidiair karakter van de vordering uit ongerechtvaardigde verrijking. Laat ons maar beginnen met deze rechtsfiguur van onder het stof te halen, zodat zij in ons privaatrecht de plaats krijgt die zij verdient. 